\title{
Modern sonrasinda dramatik metinler \\ Dramatic Texts in Postmodern Period
}

\section{Süreyya Karacabey Çelik*}

Özet

Dramatik metinler 20.yüzyılın başından itibaren büyük değişimler göstermiştir. Bunun en temel nedenlerinden birisi temsil algısındaki ve tiyatro göstergelerindeki değişimlerdir. Bu makale, dramdaki değişimlerin genel bir görüntüsünü oluşturmaya yöneliktir.

\begin{abstract}
The dramatic texts have been changed quiet radically since the beginning of the twentieth century. The main reason of this transformation is the changes in the conception of representation and theatre signs. This article aims to display a general survey of this transformations.
\end{abstract}

Dramatik metinlerdeki çözülmelerin temeli, tiyatro ile dram arasındaki ayrışmalara dayanmaktadır. Klasik temsil anlayışının çözülmesinin yol açtığı bu gerilimin, tarihsel avangardlar döneminde "tiyatronun tiyatrosallaşması" (Meyerhold) sloganında dile getirildiği bilinmektedir. Teatrallik, Jakobson'un "yazınsallık" terimine nazire olarak geliştirilmiş ve tiyatronun kendine özgü araçlarını işaret etmek üzere kullanılmıştır. Tiyatronun kendine özgü araçları ise, sahnenin şimdisinde gerçekleşen ve seyirciyle iletişimin yeni bir tanımını

* Dr.,Okutman, DTCF Tiyatro Bölümü 
gerektiren süreçler olarak formüle edilmektedir. Sahnenin seyirciyle ilişkisi, "dış iletişim sistemi" olarak nitelenmektedir, bir kurmacanın anlatımı olan dram ise, sahneyle bütünleşerek "iç iletişim sistemi"ni oluşturmaktadır. Klasik temsil anlayışında, bir kurmacanın sahne üzerindeki gösterimi -iç iletişim sistemi- kapalı bir bütün oluşturmaktadır. İç iletişim sistemi ile dış iletişim sistemi arasındaki gerilim, klasik dramatik metinlerin de varlık koşulunu oluşturmaktadır. Tiyatronun tiyatrosallaşması ya da Tairov'un deyişiyle "zincirlerinden kurtulması" ile gerçekleşen değişim, tiyatronun, ikonik göstergeleri birinci sıraya yerleştirerek, simgesel göstergeleri (dil) ikincilleştirmesidir. ${ }^{1}$ Tiyatronun, seyirciyle etkileşimi içine alan yeni işlevinin, şimdi ve burada'lık özelliği, dramatik metnin, dışarıdaki bir zamanı ve zemini işaret eden kurmaca dünyasının zamansallığı ile örtüşmeyecektir. Dram, tiyatroyla eşzamanlı bir oluşum ilişkisi kuramadığı için, tiyatronun müdahalesiyle ya azaltılacak ya da değiştirilecektir. Özerk bir sanat olma arzusundaki tiyatro, kendi sahnesel potansiyeline dikkat çekerek, görsel olan ile dilsel olan arasındaki eski gerilimi, görsel olanın lehine besleyerek, dramatik formu bir sorun haline getirmiştir. ${ }^{2}$ Teatrallik kavramının, edebi ve geleneksel temsil estetiğinin taşıyıcısı olan drama karşı çıkış olduğu söylenebilir. Tarihsel avangardlar döneminde ortaya çıkan teatrallik, yazarları da etkilemiş, metinlerinde dilsel göstergenin

\footnotetext{
${ }^{1}$ Jurij Striedter, "Einleitung", Dramatische und Theatralische
} Kommunikation, (hrsg.H.Schimid, J. Striedter), Narr Verlag, 1992., s. 7. ${ }^{2}$ Dieter Borchmeyer, "Theater (und Literatur)", Moderne Literatur in Grundbegriffen, (hrsg.D. Borchmeyer, V. Zmegac), Frankfurt/M., 1987., s. 372 
anlatıcı işlevini çözerek ya da oyun kişilerini kuklalara dönüştürerek, bu çabalara katılmışlardır. Yalnız tiyatro alanında değil, diğer tüm sanatlarda da yaşanan temsil krizi, gerçekliğin algılanması ve ifade edilmesinde yaşanan değişimin bir sonucudur. Klasik temsil estetiği, referans alınacak bir dış gerçeklik algısına temellenir. Rönesansla birlikte gelişen ve Descartes'ın bilinç ile nesne arasında yaptığı ayrımdan beslenen bu temsil anlayışında, esas olan bir gerçekliği göstermektir. ${ }^{1}$ Sanat, gerçekliği göstermek için, kavratmaya çalıştığı gerçekliğe bağlı bir "anlamsal dizge" oluşturur. ${ }^{2}$ Sanatın işlevi, gerçekliğin "öznel bir eyleme" bağlanmış imgesini çıkartmaktır. Bu işlev, gözlemci ile gözlemlenen arasındaki ayrım dolayımında oluşur. Atıfta bulunulan dış gerçeklik, sanatçı öznenin perspektifinden algılanarak yapıtında, tamamlanmış bir bütünlüğün sunumu olarak gösterilecektir. $\mathrm{Bu}$ estetik algıda bütün biçimleme araçları temsilin hizmetindedir; algılanan gerçeklik betimlenerek, anlatılarak yeniden üretilir. Bu temsil anlayışında gösteren ve gösterilen ilişkisi bir birlik oluşturmaktadır. Gösteren gösterilen ilişkisinin parçalanmasıyla, gösterenlerin bağımsızlaşarak anlamdan arınmalarının sağlanmasıyla, sanat "soyutlama" evresine girecektir. Artık sanat kendi işlevini, biçim ve içeriğin dolayımında sunan bir anlatım modeli olarak görmeyecek, kendini "karş1-kurmaca"1 olarak, temsil edici olmayan bir söylem olarak açıklayacak ve anlamdan arınmış işaretlerin kendiliklerine-

\footnotetext{
${ }^{1}$ Ian Watt- Roland Barthes, Roman ve Gerçek Etkisi, çev. Mehmet Sert, Corpus Yay., 2002., s.14 "modern gerçekçilik(...) bireyin duyuları yardımıyla hakikati keşfedebileceği görüşünden yola çıkar."

${ }^{2}$ G. Poshmann, 1997. s.. 25
} 
materyal değerlerine vurgu yaparak, temsil edici olmayan bir sanatsal yöntem geliştirecektir. Eski biçiminde sanat, gerçekliği anlamsal dizge ile sunma görevini üstlenmişti, avangardlarla birlikte gösterenin materyal değerine yapılan vurguyla bir başka temsil anlayışına geçilmiştir. Rolf Schafer, materyalin somutlandığ 1 ya da soyutlandığ sanatsal durumlarda -Kübizm, dışavurumculuk, konstruktivizm- klasik temsil estetiğinde baskın olan "anlamsal dizge"nin yerini "sözdizimsel dizge"ye bıraktığını belirtir. Artık gerçeklik, tamamlanmış bir bütünün sunumu olarak gösterilmeyecek, oluşturulacaktır. ${ }^{2}$ Sanatsal ifade biçimlerinde yaşanan bu değişimin, renk, 1şık, form, dil gibi gösteren materyallerin öz-farkındalıklarının vurgulanması ile kendi niteleme özelliklerinden uzaklaştırılarak, alımlayıcı ile anlam oluşturması 20. yüzyıl sanat biçimleri için tipiktir.

Öteki sanatlarda temsil edici olmayan estetiğin niteliği ile tiyatrodaki temsil etmekten kaçınan estetik arasında, tiyatronun özel durumundan dolayı bir fark vardır. Çünkü tiyatronun tanım ölçütü temsile bağlıdır. $\mathrm{Bu}$ alanda temsil edici estetiğin çözülmesi Poschmann'ın belirttiği gibi, diğer sanatlardan daha ağır sonuçlara yol açacaktır. ${ }^{3}$ Tiyatroda, gösterenlerin materyal değerine yapılan vurgu, E: Fischer Lichte'nin Semiotik des Theaters ("Tiyatronun Göstergebilimi") nde açıkladığı gibi, tiyatronun bir şeyi işaret etme

${ }^{1}$ Odo Marquard, "Kunst als Antifiktion", Funktionen des Fiktiven(Poetik und Hermeneutik)X (hrg.D.Herich,W. Iser). München, 1983.

${ }^{2}$ Rolf Schafer, Asthetisches Handeln als Kategorie einer interdisziplinaren

Theaterwissenschaft, Aachen,1988., s.100

${ }^{3}$ G. Poschmann, 1997., s. 27 
işlevini ortadan kaldırmaz. ${ }^{1}$ Tiyatronun ayırıcı özelliği, gerçek dünyanın heterojen materyallerini gösterge olarak kullanmasıdır. Bir "göstergenin göstergesi" olarak tiyatro, gerçek nesneleri kurmaca bir dünyanın içine gösterge olarak yerleştirir ve nesneler, ikili anlam kazanmış olurlar. Gerçekliği temsil ederken tiyatro dış dünyayla aynı materyalleri kullanmaktadır. Bir nesne sahnede, hem gerçek kullanım işleviyle hem de göstergesel kullanım işleviyle yer alır. Bu materyalözdeşliği yüzünden "kurmacanın teatral sunumu, zaten temelde, bir göndergesel yanılsamanın işlev kazanmasıdır."1 Seyirci, gösterenin ve göndergesinin aynı materyal olmasından dolayı, göstergenin göndergesini algıladığını düşünürken (örneğin, oyunda sandalye kullanılıyorsa, bu nesnenin göndergesini "sandalye"yi algıladığını düşünürken) gerçekte, o sırada sadece gösteren vardır. Bunun anlamı da, sandalyenin oyunda, bir dağ, bir merdiven vb. biçimlerde çoğaltılabilecek sahnesel kullanıma sahip olmasıdır. Sahnede gerçekleşen olaylar ile kurmacanın gönderdiği dünya arasında, kesintisiz bir referans değişimi vardır; nesnenin sahnede görünmesi ile yorumlanması birbirine paralel ilerler. Dolayısıyla tiyatro temsil edici bir sanattır ve temsil krizi, dramatik metinler için de edebi metinlerle karşılaştırıldığında daha sorun yaratıcı sonuçlara yol açmaktadır. Örneğin edebi metinler klasik biçime uygun yazıldıklarında, temsil edici bir dil kullanırlar; dile yönelik kuşkuların yol açtığı sözel temsil krizinin sonucunda ise, dilin, iletişim aracı olarak belirlenen klasik anlam taşıyıcı işlevini reddederler. Dil, kendine vurgu yapan bir nesne

\footnotetext{
${ }^{1}$ Erika-Fischer Lichte, Semiotik des Theaters Band 2, (Gunter Narr Verlag,
} 1983), s. 180 
olarak "arı biçim"de kullanılır ve böylece edebi metinler, dilin sınırlarından kurtulmuş olurlar. Otomatik yazımı, dilin anlamsal sınırlarından kurtuluşuna örnek olarak vermek mümkündür. Fakat dramatik metinde oluşturulan dil, kendi başına varolmaz, sadece okunmak için değildir; sahnenin dolaylı iletişim sisteminde dil, oyuncuya bağlıdır. Metinde tasarlanmış figürler ve bu figürlerin konuşmaları -onların isteminden bağımsız- fiziksel oyuncuya bağlanarak, bir iletişim aracı olarak kurulur. Metindeki roller nasıl yazılırsa yazılsın, oyuncunun bu rolleri okumasının geleneksel kalıplar dişında bir yolu yoktur. Joachim Kaiser, "anlamdan kaçma ve kişisellikten arınma olarak görünen eğilim, tiyatroda tutarlı bir biçimde yürüyemeyecektir. $\mathrm{O}$ insanlar tarafından oynanır. Kişisellikten arındırma çabalarına karşın, malzemesi insandır" ${ }^{2}$ sözleriyle, dram alanının zorunlu olarak temsil edici bir estetiğe bağlı olduğuna dikkat çekmiştir.

Dramatik metinler dilsel göstergeleri, ikonik göstergeleri dikkate alarak kullanmak zorundadırlar ve tiyatroda ikonik göstergeler de, yukarıda belirtilen ayırıcı özellikleri yüzünden kendilerine işaret etme işlevleri hep korunacaktır. Dilsel soyutlama oyuncunun fizikselliğinde somutlanırken, göstergenin somutluğuna yapılan vurgu da, onu bir şeylerin işareti olmaktan tümüyle kurtaramayacaktır. Dram ile tiyatro, geleneksel olarak mimetik sanatlar olduğu için, bu alanlardaki temsil krizi, diğer sanatlardan daha yoğun bir "estetik

${ }^{1}$ a.g.e. s. $184,185$.

2 Joachim Kaiser, "Grenzen des modernen Dramas: Vortrag, gehalten auf dem Germanistentag in Essen”, Theater Heute, Heft-12, 1964., s. 14 
meydan okuma" olarak belirginleşmektedir. Temsil krizi gerçeklik algısındaki değişimle yakından ilgilidir ve :

Avrupa edebiyat tarihi açısından sanatın kendi yaratıcı potansiyeli lehine, mimetik-gerçekçi bir hakikat temsilinden vazgeçmesi büyük bir kırılmadır ve Baudelaire'den beri simgeci sanatın 'çeşitlenmiş' görüş ve gerçekliği sanatın ayrılmaz parçası kıldıkları bilinir. ${ }^{1}$

Gerçeklik algısı değişmiştir ve Nietzsche'nin erken bir tarihte "tüm gerçekliğin kurmaca karakteri" saptamasında dile getirdiği durum, sanatın gerçeklikle ilişkisini sorunlu bir zemine kaydırmıştır. Gerçekliğin sanat yoluyla üretiminde (klasik temsil) kendi dışında referans alabileceği bir öz kalmayınca, dışındaki dünyayla eski anlamsal bağını yitirecektir. Kurmaca ile gerçeklik arasındaki ayrımın silinmeye başladığı bir noktada, sanatın kurmaca niteliği de "karşıkurmaca"ya dönüşecektir. Dramatik metinler de kurmaca dünyalarını gerçekliğin bir biçimi olarak ele almaya başlayacaklardır. Odo Marquerd, "Karş1-Kurmaca Olarak Sanat" başlıklı denemesinde, kurmaca-gerçeklik ilişkisinin paradoksal bir biçim almasına dikkat çeker:

Gerçek ve kurmaca aslında karşıttılar; fakat yaşadığımız zamanda artık değil, gittikçe gerçek ve kurmaca alaşım olarak görünmekte (..) Sanat kurmacanın bütününden gerçekliğe dönüşüyor -kendi açısından karşı kurmacaya ${ }^{2}$

\footnotetext{
${ }^{1}$ J. Striedter, Ön.ver.,1992., s. 8

${ }^{2}$ O. Marqued, 1983., Ön.ver. s. 54
} 
Nietzsche'nin "gerçekliğin kurmaca karakteri" tespitiyle, yaşanılan zamanın gerçeklik algısı arasındaki benzerlik dikkat çekicidir. Yaşanılan dünyada televizyon, video ve daha yeni enformasyon teknolojilerinin gelişmesiyle algının total olarak araçsallaştığı ve gerçeklik ile kurmaca arasındaki sınırların kaybolduğundan söz edilmektedir. Baudrillard'ın "simülasyon" benzetmesiyle açıkladığı toplumsal yapıda, gerçeklik ve suretleri birbirine karışmış, gerçeklik yeniden üretilir olanın eşdeğeri haline gelmiştir. ${ }^{1}$ Gerçeklik deneyimi artık kendi içine kapalı, hesaplanabilir algı kodlarına temellenen ve sadece kendini işaret eden bir göstergeler sisteminden elde edilmez. Gönderge-anlam uçucu bir şeye dönüşmüş ve gerçekliğin sınırlarından uzaklaşılmıştır. Baudrillard'a göre, "gerçeklik bir yanılsamadır ve her düşünce öncelikle onun maskesini çıkarmak zorundadır." ${ }^{2}$ Suretlerin asıllarından daha gerçek bir şeye dönüştüğü bu durum "hipergerçeklik" durumudur ve, "simülasyonun ufkundan" kaybolan bir dünyada her şey tiyatrodur; ama her şey tiyatro haline geldiğinde, ortada herhangi bir sahne, mesafe, bakış kalmaz. "Gölgeler krallığında, artık kimsenin gölgesi yoktur"3 diye sürdürür Baudrillard; batı felsefesinde merkezi bir konum oluşturan karşıt çiftler (özne/nesne; beden/düşünce vb.), bu karşıtlıklara dayanan düalizm artık yıkılmıştır. Gerçeklik ile kurmacanın birbirinden kesin sınırlarla ayrılabilmesi için, gerçekliğin "otantik" bir algısına ihtiyaç vardır. Oysa çağdaş dünyada, "gerçekliğin kaydı değil inşası" söz

\footnotetext{
${ }^{1}$ J. Baudrillard, 1998., s.12

2 J.Baudrillard, Kusursuz Cinayet, çev. Necmettin Sevil, Ayrıntı Yay., 1998., S. 119

${ }^{3}$ J. Baudrillard, a.g.e. s. 47
} 
konusudur ve "önceden formatlanmış" suretlere koşullanan bir algı biçimine bağlanmış bir dünyada, gerçeklik ve kurmaca ilişkisindeki bu belirsizlik temsil krizinin temelidir. İşaret ile işaret edilen arasındaki geleneksel ilişkinin kopmasını Foucault, benzerliklerin yerini ayrımlara bırakması olarak açıklar:

19. yüzy1lın tümü boyunca ve günümüze kadar, -Hölderlin'den Mallarme'e, Antonin Artaud'ya, edebiyat ancak derin bir kopuştan geçip, bir cins "karşs-söylem" oluşturarak ve böylece dilin temsili ve işaret eden işlevinden,16.yüzyıldan beri unutulmuş olan şu ham varlığa geçerek özerk olabilmiş, diğer bütün dillerden ayrılabilmiştir. ${ }^{1}$

Foucault, ünlü gerçeküstücü ressam Magritte'in, altında "bu bir pipo değildir" yazan pipo resmi üzerine yaptığı bir incelemede, "canlandırıcı ileri sürüş ile andırışın eski suç ortaklı̆̆ı"nın yok olduğunu göstermiştir." ${ }^{2}$ Sözcüklerle nesneler arasındaki organik ilişkinin koptuğu bir dünyada,

Saussurecü dilbilimde sözcüklerin şeylere 'gönderim'de bulunmaması gibi, Magritte'in gerçeküstücülüğünde de ressamın görüntüleri, egemen varlığı dolayısıyla bir model ya da köken görünümü edinen herhangi bir şeye 'benzemez'1

Dünya gösterenlerle gösterilenlerin keyfi ilişkisinde, eski anlamını yitirmiş, öznel algının itibarı çözülmüş ve insan, "denizin sınırında kumdan bir yüz gibi" silinmiştir.

\footnotetext{
${ }^{1}$ M. Foucault, 1994., s.77

${ }^{2}$ M. Foucault, Bu Bir Pipo Değildir, Çev.Selahattin Hilav, YKY, 1993., s.48
} 
Temsil krizini bir mimesis krizi olarak görmemek gerekir. Temsil, estetiğin bir kategorisidir. Oysa mimesis, Aristoteles'den bu yana, dar anlamda bir taklit olarak anlaşılmaktadır. ${ }^{2}$ Bundan dolayı, Poschmann'ın Friedrich Tomberg'den aktardığına göre, temsil edici olmayan bir sanatta da, değişen gerçeklik anlayışına uygun bir mimesis var olacaktır. "Bilincin ya da bilinçsizliğin taklidi" olarak mimesis, değişen sanat anlayışına kendisini uyduracaktır. ${ }^{1}$ Bir estetik ilke olarak temsilin klasik biçiminin anlamsal dizgeye bağlandığı söylenmişti ve klasik temsilin varlık koşulunun da referans alabileceği bir dış gerçekliğe gereksinim duyduğu. Temsil anlayışında Schafer'in dile getirdiği sözdizimsel dizgeye geçişin bağlı olduğu soyutlama ya da somutlama evresinde, "dil, renk, 1şık, biçim" gibi sanatsal gösterenler, kendilerine vurgu yaparak, kendilerini mutlaklaştırırlar ve böylece bir şeyi anlamlandırma işlevleri ortadan kalkar. Anlam oluşumu da ancak alımlayanın dahil olduğu bir sürecin sonunda oluşur. Bir kurmaca sanatı olan dramda, temsil edici estetikle yaşanan sorunların, tarihsel avangardların "tiyatrosallaşma" amaçlarıyla başladığı ve postdramatik tiyatronun "edebiyattan arındırma" çabasıyla ikiye katlandığı söylenebilir. Dramatik metinlerin, bir şeyleri temsil eden yapısı, öykünün reddedilmesiyle, ikonik göstergelerin birinci sıraya yerleştirilmesiyle parçalanmaya başlamıştır. Tekrarlanacak olursa, klasik temsil estetiğinin, gerçeklikle kurmaca arasında kesin bir ayrımın yapılabildiği bir dünya algısına temellendiği, bu ayrım bulanıklaştıkça temsil krizinin ortaya çıktı̆̆ı ve

\footnotetext{
${ }^{1}$ M. Foucault, a.g.e. s. 12

${ }^{2}$ Aristoteles, 1987., s..12,13.
} 
temsil krizinin teatrallik anlayışıyla birlikte dramatik metinleri yapıbozumuna uğrattığı söylenebilir.

20. yüzyılın ilk y1llarında tiyatronun tiyatrosallaşması isteğinin altında, yeni bir tiyatronun seyirciyle kuracağı ilişkinin işlevine yönelik bir propaganda vardı. Tiyatrodaki değişim için "sahne ve seyirci arasındaki ilişkinin yeniden örgütlenmesi"ne dikkat çekilmekteydi. Sahnede 1şık, renk, ve mekan gibi sahneleme unsurları soyutlanıyor, müzik, koreografi gibi soyut sahne göstergeleri daha yoğun bir biçimde kullanılıyordu ve onların da gösterge karakteri yerine materyal değerlerine vurgu yapılıyordu. Avangard tiyatro, oyuncu ve rol figürünün ayrılmaz görünen birliğini parçalayıp, onun yerine bedensel göstergelerden oluşan bir sistem yerleştirmeye çalışıyordu. Tiyatrosallaştırma tasarısı, her şeyden çok edebi ve geleneksel temsil estetiğinin taşıyıcısı olan drama karşıydı. Bu dönemin yazarları da dilsel göstergenin işlevini çözerek bu çabaları desteklerken, teatrallik, tiyatronun ayırıcı bir özelliği haline gelmişti. Meyerhold, "Sözcükler, tiyatroda hareket kanavası üstüne işlenen desenlerden başka bir şey değildir.(...) Özellikle bir diyalog, bir çatışma, gerilimli bir diyalektikten oluşan dram, okunmak içindir." diyordu. Meyerhold, Commedia dell'Arte kanavası gibi, sadece pantomim unsurları içeren yeni bir dram anlayışına dikkat çekmekteydi. Bu tiyatroda, jestler, sözcükler tarafından düzenlenmeyecek, sözcükleri yönetecekti. Tiyatronun kendi iç gerçekliğinin yapılandırılması olarak kavrandığı bu anlayışta,

${ }^{1}$ G. Poschmann, 1997., s. 26 
tiyatronun tiyatro dışındaki bir dünyayla (öykünün gösterdiği kurmaca dünya) özdeşlik kurmasından vazgeçme arzusu vardı. ${ }^{1}$ Tiyatro dışı bir dünyayı kendi kurmacasında somutlayan dramatik metnin sorun yaratması kaçınılmazdı. Artaud'nun dile yönelik eleştirileriyle daha uç noktaya taşıdığı dilsel metinden kaçma eğilimi sonraki yıllarda da sürdürülecekti. Artaud, Kıyıcı Tiyatro'nun ilk manifestosunda,

Çünkü kendiliğinden anlaşılacağı üzere, tiyatro fiziksel yönüyle ve aslında tek gerçek anlatım olan uzamda anlatımı gerektirmesinden ötürü, sanatın ve sözün büyülü olanaklarının, yinelenen şeytan kovma ayinleri gibi, organik olarak ve bütünlükleri içinde kendilerini duyurmalarını sağlar. Bütün bunlardan, tiyatroya dilini geri vermeden, onu kendine özgü eylem gücüne yeniden kavuşturulamayacağı sonucu çıkıyor.(...) tiyatronun metne bağımlılığını kırmak ve jestle düşünce arasında kalan bir tür benzersiz dil kavramını yeniden bulmak önemlidir. $^{2}$

Sözleriyle tiyatroda yeni bir dil arayışına dikkat çeker. Derrida, Artaud okumalarında, burada talep edilen dilin, kavram öncesi bir dil oluşuna dikkat çeker. Kendi görüntüsünü kendi oluşturan bu dil, temsilin mantığına hizmet eden, telaffuzu dilbilgisi kurallarına uyan yazılı kelimelerin dilinden farklıdır. Dil aracılığıyla sağlanan uzamlaştırma, yeni bir uzam kavramına ve özel bir zaman tasavvuruna yapılan bir çağrıdır. Bu uzamlaştırma, tümüyle dilin fiziksel-somut varlığına bağlıdır ve teolojik değildir. Derrida, teolojik

\footnotetext{
${ }^{1}$ Meyerhold, 1997., s. 251

2 A. Artaud, 1993, Ön.ver.., s. 79
} 
uzamı, geleneksel-kavramsal dil tarafından tiyatro alanı dışındaki bir uzama işaret eden ve bu uzamı baskın kılan anlayışta görmektedir. Derrida'ya göre,

olmayan bir yaratıcı (yazar), uzaktan bir metni kuşanarak (metinle silahlanarak), zamanı ya da temsilin anlamını gözetler, birleştirir ve yönetir. Temsilde, temsil edilenler, doğrudan onun (yazarın) düşüncelerini, hedeflerini adlandırmakla yükümlüdür. Temsil ediciler aracılığıyla temsil edilenler -rejisör ya da oyuncular- boyunduruk altındaki kişilerdir, demek ki, buna göre az ya da çok 'yaratıcı'nın düşüncelerini temsil ederler. ${ }^{1}$

Artaud sahnenin dışındaki bir akla temellenen ve gösterime dayanmayan anlayışın hakimiyetini eleştirmiştir. Derrida, bu hakim anlayışın dilin mantığına bağlı olduğunu belirtmektedir.

Tüm imge dolu, müzikal hatta jeste dayalı biçimler batı tiyatrosuna girdiğinde (...) kendini her şeyin başlangıcı olarak niteleyen bir metni görüntülemek, ona hizmet etmek, eşlik etmek ve onu süslemekten fazla bir şeyi başaramaz. ${ }^{1}$

Batı tiyatro kültüründeki söz-merkezciliğin baskın rolü teşhir edilir ve bu söz-merkezcilik Kıyıcı Tiyatro'da, köken temsile dönüş arzusuyla, kavram öncesi ifade biçimlerinin geliştirilmesiyle, kelimelerin fonetik yapısına (tını, vurgu, şiddet) vurgu yapılmasıyla ve dilsel ifadenin çığlık, ses gibi dilin fiziksel görünümlerinin ön plana

${ }^{1}$ J:Derrida, "Das Theater der Grausamkeit und die Geschlossenheit der Reprasentaion", Schrifft und Differenz, Frankfurt/M., 1976., s.359 
çıkarılarak azaltılmasıyla, yok edilmeye çalışılmıştır. Artaud, bu yeni tiyatro dilini şöyle tanımlamaktadır:

Söz konusu olan, eklemli dilin yerini, farklı doğada bir dilin almasıdır, bu dilin anlatım olanakları sözcüklerin diline eşdeğer olacak, ama kaynağını, düşüncenin daha derin ve daha uzak bir noktasından alacaktır. Bu yeni dilin, dilbilgisinin de bulunması gerekiyor. Jest onun maddesi ve başıdır; isterseniz alfası ve omegası deyin. $\mathrm{O}$, hazır biçim verilmiş sözden çok, sözün GEREKLİLİĞİ'nden yola çıkar. İnsana özgü somut anlatım yasalarının bazılarına, geçerken şöyle bir dokunur: Gerekliliğin içine dalar. Sonu dilin yaratılmasına varan yolu, şiirsel olarak yeniden kateder. Ama, sözü dille devingenleşmiş dünyaların iyice bilincine vararak ve onları tüm görünümleriyle yeniden yaratarak. ${ }^{1}$

Bütün bu eleştiriler dramın "mutlak" yapısını ihlal edecek girişimleri beslemiştir; sahneleme olanakları olarak anlaşılabilecek teatrallik ile dramatik metinler arasındaki gerilim sonucunda dönüşsüz bir sürece girilmiş olunur.

Yukarıda belirtilen anlam doğrultusunda sürdürülen arayışların, 20. Yüzyılda "yönetmen tiyatrosu"nu birincil konuma getirmesi kaçınılmazdır. Tiyatronun asal yaratıcısı, kurmaca metnin yazarı değil, sahnesel süreci seyirciyle iletişime sokarak yeniden anlamlandıran yönetmendir. Yönetmen tiyatrosunun dramatik metne yaklaşımı iki biçimde gerçekleşir: en iyi durumda dramatik metni,

${ }^{1}$ J. Derrida, a.g.e. s. 359 . 
sahnelemenin diğer unsurlarıyla eşdeğer görür; daha radikal uygulamalarda ise, metni tiyatroya karşıt bir unsur olarak ele alır. Teatrallik kavramının ilk görünümü olarak nitelenen "sahnesel teatrallik", sahnesel olanın metne karşı ayrıcalıkı kılınmasıdır. Zaman içindeki gelişmeler, teatralliğin bu ilk görünümünü (sahnesel teatrallik) erken bir teatrallik anlayışına dönüştürecektir. Helmar Schramm, değişen dünya algısına bağlı olarak teatralliğin, dramın içerdiği teatral potansiyel olarak görülebileceğini belirtir. Dilin asal bir niteliği olarak yorumlanan teatrallik, bu anlayışta, dramatik metnin içsel bir kategorisi olarak belirir. Teatrallik anlayışındaki değişim, dilin temsil edici işlevinin dışındaki bir dünya algısına bağlanır. "Değişmiş bir düşünce üslubu için dramatik metnin, yazılı dilin çizgisel ardıllık yönelimine karşı tasarlanması gereklidir." ${ }^{2}$ Dilsel metindeki teatrallik potansiyeli, oyuncu-alımlayan ilişkisine de, sözmerkezli bir kültürün anlam üretimine de eleştirel bir bakış olarak yorumlanabilir. Dilin performans niteliğine yapılan vurgu, dilin geleneksel algısının değiştiğini bildirmektedir. Özellikle yeni tiyatro metinlerinin çözümlenmesi için bir anahtar işlevi gören metinsel teatrallik, tiyatroda değişen anlayışa metin yazarlarının bilinçli bir katılımı olarak yorumlanabilir. Tiyatroda değişim arzusunun sahnesel teatrallikle başlayıp, daha sonra bu anlayışı destekleyen yazarların geliştirdikleri yazma biçimleriyle ortaya çıkan metinsel teatralliğin, dramatik metinlerin içerdiği dramatik potansiyelle aynı şey olmadığı

\footnotetext{
${ }^{1}$ A. Artaud, 1993, Ön.ver.., s. 97.

${ }^{2}$ Helmar Schramm, "Theatralitat und Öffentlichkeit", Asthetische Grundbegriffe.Studien zu einem historischen Wörterbuch, (hrsg.Wolfgang Thierse), Berlin 1990., s.202-242.
} 
dikkatten kaçmamalıdır. Dramatik potansiyel, dramı diğer edebi metinlerden ayıran özelliklerin bir toplamıdır. Örneğin, Regis Durand'ın dramatik metinlere edebiyatla aynı ölçütlerle bakılamayacağını, çünkü dramatik metinlerin mekansallık ve materyallik düşüncesine bağlı oldukları yolundaki açıklaması, dramatik potansiyele aittir. Ya da Roland Barthes'ın, "yazılmış metin,durumların, nesnelerin, bedenlerin, kelimelerin özünde çınladığ1 formlardan oluşur", belirlemesi de dramatik potansiyeli anlatmaktadır.

Helga Finter, metinsel teatralliği ikiye ayırır ve ilkini, geleneksel teatrallik, ikincisini de analitik teatrallik olarak adlandırır. ${ }^{1}$ Finter'in geleneksel teatrallik kavramı, sözü edilen dramatik potansiyeli içine almaktadır ve bu da metnin aracılık özelliğine bağlıdır. Dramatik metinlerin taşıdığı potansiyel, bir dolayıma bağlıdır, sahnede gerçekleşecek olayların bir elçisi olarak bir aracılık özelliği taşımaktadır. Analitik teatrallik ise, kurmaca içini aşar ve sahnedeki dış iletişim ortamını dikkate alarak "alımlama çerçevesine" bağlı olarak oluşur. Teatrallik böylece, "postdramatik tiyatroda öykünün sahnesel olana araç oluşunun stratejileri ve temsil edilen olayların özelliklerinin bir toplamı değil, gösterim anındaki algısal yaşantının bir niteliği olarak" tanımlanmaktadır. Dramatik potansiyel ya da geleneksel metinsel teatrallik, yalnızca, kurmacanın sahnede olacakların olası elçisiyken ve metin içi -kurmaca içi iken; analitik teatrallik, kurmacayı aşmakta ve yazarın sahneleme sırasındaki

\footnotetext{
${ }^{1}$ aktaran:Gerda Poschmann, 1997. s. 31
} 
iletişim ortamını dikkate alarak yazmasıdır. Teatralliğin bu biçimi, yeni metinlerin bir özelliği olarak nitelenebilir.

\section{Postdramatik Tiyatro}

Dramatik metinlerin tiyatrodaki işlevi konusunda en radikal tutumlardan birisi, postdramatik tiyatro anlayışında sergilenmektedir. Postdramatik tiyatro, metnin azaltılabileceğini savunurken, tiyatroyu, metnin, öykünün "öteki tarafindaki" sinırda görür; performans, happeningler ya da Robert Wilson'un "imge tiyatrosu" gibi örneklerle bütünleşerek, dramatik metinden uzaklaşma arzusunu belirginleştirir. Hans-Thies Lehmann, postdramatik tiyatroyu "dramın öteki tarafi" olarak nitelemiştir. ${ }^{1}$

$\mathrm{Bu}$ tiyatro yoğun olarak projelerin formunda oluşur, bir rejisörün yanında, bir sanatçılar timi farklı türleri ortaklığa çağırırlar. Dansçılar, grafikerler, müzisyenler, oyuncular, mimarlar -belirli bir projeyi gerçekleştirmek için ortak çalışırlar. ${ }^{2}$

$\mathrm{Bu}$ tiyatronun oluşum özelliği deneyselliktir; nefes, ritim gibi "canlı bedenin şimdisine ait unsurlar" sözden önce gelir. Lehmann, metnin yeni konumunu, yapı-bozumu ve çok-seslilik kavramlarının çerçevesinde açıklamaktadır. Tiyatronun tüm unsurları gibi dil de bir anlam bozumunu gerçekleştirecektir. Diyalog ise yerini çok-sesliliğe bırakmıştır. Dilin başat unsurlarının görsellik tarafından "durdurulduğu" bu tiyatroda, tiyatro metni "sahnenin dışındaki

\footnotetext{
${ }^{1}$ H. T. Lehmann, 1999., s. 30

2 a.g.e. s..36.
} 
dünya", "yabancı beden" olarak ele alınacaktır. ${ }^{1}$ Dilin bir şeyleri göstermesi, anlatması yerine, seslerin, sözcüklerin, cümlelerin, tınıların anlam oluşturmayan durumlarının sergilenmesi hedeflenir. "Olmak ile anlam arasındaki kırılma şok etkisi" yaratacaktır. Dil, postdramatik tiyatroda sergilenen bir nesne haline gelmiştir. Dilin sergilenen nesne olması, açık anlamsal bağlantılarından ayrılmasıyla gerçekleşmiştir. Anlamsal bağlantılardan ayırma, tekrarlarla, sözdizimsel ya da müzikal ilkelere göre yapılan düzenlemelerle elde edilir ve dil, "sergi nesnesi" haline getirilir. ${ }^{2}$ Ya da Peter Handke'nin "konuşma oyunlarında"örneğin Publikumbeschimfung, Heiner Müller'in Bildbeschreibung oyununda olduğu gibi, dilin unsurları yalıtılıp, parçalara ayrılır. Postdramatik tiyatroda, kolaj ve montaj yanında çok-dillilik de ilkesel bir seçimdir. Lehmann'a göre, çok-dilli tiyatro metinleri, ulusal dilin birliğini bozacaktır. Lehmann, 1991 yılında gerçekleştirilen, "Römische Hunde”(Romalı Köpekler) projesini örnekler:

Heiner Goebbel'in, Heiner Müller'in Almanca, William Faulkner'in İngilizce metinlerinden ve Corneille'in Horace yapıtından yapılan bir kolajdan oluşmuştur. Oyuncu Catherine Jaumioux, bu kolaj1 çoğunlukla şarkı ve resitatif olarak yorumlamıştı. ${ }^{3}$

Lehmann, bu türden uygulamalarda amaçlananın, dilsel iletişimin güçlüğünü vurgulamak olduğunu ve seyirci için olduğu

\footnotetext{
a.g.e. s. 266

2 a.g.e. s. 266

${ }^{3}$ a.g.e. 1999., s. 270
} 
kadar oyuncu için de dilin engelleyici bir unsur haline geldiğini belirtmektedir.

Dil, konuşandan koparılarak alışılmış algı kalıpları kırılacaktır ve dil, kekemelik, aksan ve yanlış telaffuzla kullanılarak beden ve kelime arasındaki çatışma belirginleşecektir. Lehmann, postdramatik tiyatroda metnin yeni konumuna uygun olarak, peyzaj metin kavramını önermektedir. ${ }^{1}$ Çıkış noktası ise, Wilson'un ideal bir tiyatronun, sessiz film ve radyo oyununun birleşiminden oluşması gerektiği yolundaki düşüncesidir. Radyo oyunu, görsel hayal gücünü, sessiz film de işitsel hayal gücünü harekete geçirecek ve bu yolla da uzamın sınırları aşılacaktır.

Postdramatik tiyatro, "eylemin öteki tarafı"na yerleştirilmiştir. Dramatik tiyatro, kendini eylemle açiklarken, postdramatik tiyatroda eylem yerini duruma ve dinamik sahnesel oluşuma bırakmıştır. Artık dramatik eylem, dram öncesi dönemlerde olduğu gibi, ayine bağlıdır. $\mathrm{Bu}$ ayin, bir ölü gömme törenidir, Jean Genet'nin "tören" olarak adlandırdığı tiyatronun yerini, mezarlık olarak belirtmesi, tiyatronun aslında bir ölüm ayini olmasına işaret etmektedir. Heiner Müller'in tiyatronun "ölülerle diyalog" olduğunu söylemesi de bu düşüncenin, postdramatik tiyatroda sürdürüldüğünü belgeler niteliktedir. Postdramatik tiyatronun önemli bir biçimleme özelliği olan törensellik, Kantor'da "sorumsuz yanılsamadan" kurtulmak ve oyun olmayan bir durumun arayış formu olarak görünürken, Beckett ve Müller'de "yıkımdan sonra kalanları" göstermektedir. Postdramatik 
tiyatro, kolektif deneyimleri kendi yapısında telaffuz etmekten vaz geçerek, bütünsel bir modelin örnekçesinde yapısal parçaları kaynaştırmaktan uzaklaşmış ve böylece de bireşim fikri yok edilmiştir. Kaos teorisiyle bağlantılandırılarak anlaşılan "istikrarsız gerçeklik" sanatsal oluşumda, çoğul değerlik ve tek anlamlılıktan kaçınma olarak somutlanırken yapıtın bir bireşim olma düşüncesi aşılmış olacaktır. Toplumsal olan benzerlerden oluşmamaktadır; tiyatro da seyircinin farklılıklarını bir bütünde kaynaştırmaya çalışmayacak, farklı, tekil fantezilerin bir toplamını sunmaya çalışacaktır. Anlamın el çekmesi, sahnenin çok katmanlı rüya benzeri yapılara açılmasıyla gösterilecek, rüya da olduğu gibi resimlerin, hareketlerin ve kelimelerin hiyerarşi dışı bir yapılandırılması esas alınacaktır. Rüya düşüncesi, kolaj, montaj, fragmana benzer bir metin oluşturmaktadır. Ayrıca postdramatik tiyatroda, organik bütünlüğe itiraz, aşırılığa eğilim, parçalama, istikrarsızlaştırma ve paradoks biçiminde kendini gösteren gösterge kullanımı geleneksel bağlantısallık ilkesinin yerini heterojenliğe bıraktığını göstermektedir. $\mathrm{Bu}$ heterojenliğin ortaya çıkaracağ düzenlenmiş anlamların dışında bırakılan seyirci, sunulan durumlarda bir bağlantının izini aramaya çalışacak ve kendisi bağlantı kurmak zorunda kaldığı için de algısı aktifleşecek, düş gücü şiddetlenecektir. Sunumun sahnelemeyle yakınlığının içsel bir nitelikten kaynaklanmayıp, seyirci tarafından-dışsal-kurulacak bir ilişkiye bağlanması duyum ikiliğini yaratmıştır. Lehmann, postdramatik tiyatronun üslup özelliklerini, hiyerarşiden uzaklaştırma, eşzamanlık,

${ }^{1}$ H. T. Lehmann, Ön.ver.. s. 272 
yoğun göstergelerle oyun, müzikalite, bedensellik, gerçeğin yıkımı ve durumun olaya dönüştürülmesi olarak açıklamaktadır. ${ }^{1}$ Durumun olay haline gelmesinin anlamı, tiyatronun "şimdi ve burada"lığına yapılan vurgudur.

Postdramatik kavramı, dramın sonrasına geçildiğini bildirmektedir ve öykünün, eylemin, diyalogun geleneksel biçiminin terk edildiğini belirten bu kavram, aynı zamanda, dram kavramını da tarihselleştirerek sorgulanır hale getirmiştir. Dramatik metinlerin temsil kriziyle birlikte uğradığı değişimlerin en radikal sonuçlarından birisi, postdramatik tiyatronun metne bakışıdır. Fakat tiyatronun metinden tümüyle kurtularak, özerk bir sanat olacağını düşünen metinsiz tiyatro anlayışı, postdramatik tiyatroyu da aşmaktadır.

\section{Dramatik Metinden Tiyatro Metnine}

Yönetmenler değişen tiyatro anlayışına uygun araçlarla düşünürken, klasik dram metinlerini de kullandıkları görülmektedir. Fakat metni, merkezsizleştirerek, parçalayarak, yapısını bozarak kendi sahneleme biçimlerine uydurmaktadırlar. Klasik metinlerin yakın zamanlı sahnelemelerinde örneklerine rastlanabilecek bu eğilim, bütün değişimlere karşın metin ile sahneleme arasındaki krizin sürdüğünü göstermektedir. Çağdaş yazarların bir bölümü bu gerilimi azaltmak

1 a.g.e. s. $149-167$ 
için, yönetmen tiyatrosunun isterlerine uygun metinler yazmaktadırlar. Klasik dramın yapısal unsurlarını-eylem, figür, diyalog- metadram biçiminde oluşturdukları metinlerde, konu haline getirmektedirler. Dramın asal bileşenlerini dönüştürerek kullanan bu yazarlar, statik dram ile eylemi eylemsizliğe, klasik nedenselliği ve sonuca doğru ilerleyen yapıyı, sonsuz dönüşlerin çevrimsel mantığına oturtmakta, karakteri kişisellikten uzaklaştırarak ve diyalog yerine de monolog ya da koro kullanarak, klasik dramın tüm unsurlarını dönüştürmektedirler.

Kolaj ya da fragman olarak oluşturulan metinlerde ise, yazının materyal değerine dikkat çekmekte ve ritmik,dize diline dönüş yaparak dili, bir gösterenler zinciri olarak kullanmaktadırlar. Kelimelerinin, görüntü tarafından baskılanmasını kabul eden yazarlar, metinlerini bir sahne metni olarak tasarlamaktadırlar. Tiyatro için yazılmış olma ilkesinden hareketle oluşturulan bu metinlerin, dramatik tiyatronun dışında bir metin üretimine işaret ettikleri söylenebilir. Dramatik tiyatronun dışında kalan metinler, bu alandaki değişimlerin somut örnekleridir.

Yeni oyun yazımında diyalog, çatışmanın ve alışverişin bir kalıntısı olarak sahnelerden sürgün edilmiştir; fazla iyi düşünülmüş öykü, entrika ya da öykünceye artık kuşkuyla bakılmaktadır. ${ }^{1}$

Bir zamanlar sahnelemenin üstlendiği dramı reddetme, dramı eleştirme eğilimine sahip olan yeni metinler, anlamın çoğulluğu

\footnotetext{
${ }^{1}$ Patric Pavis, Sahneleme, Çev. Sibel Kamber, Dost Yay., 1999., s. 96
} 
ilkesinden hareket ederek tiyatroda metnin statüsünün yeniden tanımlanmasına yardımcı olmaktadırlar: Dramın öteki tarafı. Avangard dönemde yazılan metinlerdeki ütopik gelişimlerin aslında önceden bildirdiği bu değişimler, dramın artık öldüğünü söylemektedirler. Tiyatroda metinsiz tiyatro ya da "dramın öteki tarafındaki" metin denemelerine karşın "edebi tiyatro modeli ve dramatik tiyatronun söz-merkezliği"nin tümüyle ortadan kalktığ1 söylenemez, sadece göreli bir hal aldığı söylenebilir. 1980'li yılların başından beri, tiyatroda metnin yeniden güçlendiğini gösteren çalışmalar kaydedilmektedir. Bu güçlenmeyi postmodern tiyatrodaki "kitap ütopyası"na bağlamak mümkündür ${ }^{1}$. Dil ve metnin deneysel tiyatrolarda materyal olarak yeniden keşfedildiği bir dönemin iç dinamiklerinin, postmodern düşüncenin her şeyi kucaklama eğilimine, bütün biçimlerin yan yana kullanılabileceğine ilişkin açıklamalarına ve "her şey uyar" anlayışına denk düştüğü söylenebilir. Dramın alanını sinırlayan ve temsil krizine neden olan sahnesel teatrallikten metinsel teatralliğe değişim gösteren teatrallik, artık tiyatro için yazılan metinlerin bir parçası olarak ortaya çıkmaktadır. Tiyatro için yazılan çağdaş metinlerin ayrılmaz bir parçası haline gelen teatrallik, bu metinlerin yapısını dinamikleştirirken, onları "açık yapıt" haline getirecektir. Modern tiyatronun gelişim eğrileri, Szondi'nin dramda "kriz" teşhisini koyduğu zamandan bu yana ortaya konulan örnekler düzleminde dramın revizyonunu içermektedir. Dram artık sorunlu bir belirleyicidir. G.Poschmann, dramın kavramsal açılımını oluşturan unsurların, artık üretilenleri anlatmada yetersiz kalan bir sınırlamaya

${ }^{1}$ G. Poschmann, 1997., s.37 
işaret ettiğini söylemektedir. $\mathrm{Bu}$ bağlamda tiyatro için yazılan "epik"metinlerin, "dram" kavramıla nitelenmesi -epik dramsorunludur. Dram, hareketle ve eylemle sıkı sıkıya bağlı bir kavramdır, bu kavramın anlatısal olanın da üst türü yapılması açılayıcı olmaktan uzak görünmektedir. Dolayısıyla "epik dram" çelişkili bir kavramdır. ${ }^{1}$

Daha önce de belirtildiği gibi terminolojik olarak dramın bağlandığı çatışmalı eylem, diyalog ya da monologa bağlı dilsel iletişim, modern tiyatronun gelişim aşamalarında ortadan kalkmıştır. Epiğe ya da absürde yönelen eğilimler, dramın varlık nedenini ortadan kaldıracaktır. Epik, estetik ilkesini anlatısal olan biçiminde belirlerken, kendisini dramdan uzaklaştırmış olur; absürd tiyatroda egemen kılınan eylemsizlik, açıç̧a "bir eylemin taklidine" karşı çıkıştır ve dramın bir türün üst kavramı olarak kullanılması, absürd metinler için de sorunludur. ${ }^{2}$ Martin Esslin ise dramın, film ve televizyon için yazılan kurmacaları da kapsadığına dikkat çeker ve bu noktada da dram, kendi özel anlamından uzaklaşmış olacaktır. Dram kavramının yarattığı terminolojik çelişkiden dolayı pek çok metin, "oyun" olarak nitelenmektedir. Fakat oyun nitelemesi de, dilsel metinden çok sahnelemeyi akla getirmektedir. Bir başka kavram da "tiyatro metni"dir. Hans-Thies Lehmann, Heiner Müller'in bir oyununa ilişkin yazdığı makalede:

\footnotetext{
1 a.g.e. s. 41
}

2 a.g.e. s. 41 
Metin(..:) bir tiyatro festivali için yazılmıştı; Müller onun birden fazla tiyatro metni olduğunu söyledi ve sonraki sahnelemelerinde de bu nitelemeyi sürdürdü. Bir tiyatro metni hangi durumda söz konusudur? Hiçbir sahne açıklaması, tek anlamlı eylem, rol, dram yoktur. (...) dramatik ve teatral metin arasındaki ayrımlara ait bir çalışmanın başında Heiner Müller'in yeni metinleri bulunur. ${ }^{1}$

Tiyatro metninin çeşitli yazarlar tarafından kullanıldığına dikkat çeken Poschmann, artık tiyatro için yazılan oyunların "tiyatro metni" olarak adlandırılabileceğini söylemektedir. Tiyatro metninin kullanımıla birlikte, dramatik metin, bir tarihsel alt tür olarak algılanacaktır. Kişileştirme, anlatı ve kurmaca ölçütleriyle kavranan dram, belirli bir döneme ait biçimleme ilkesi olarak kabul edildiğinde bir anlam kazanmış olacaktır. Ayrıca kültürler arası bir perspektiften bakıldığında, pek çok kültürde dramın bir karşılı̆̆ olmadığ görülecektir. Tiyatro her yerde vardır fakat Avrupa merkezli dram, dünyanın bir çok ülkesinin tiyatrosunda belirli bir tarihten sonra öğrenilmiş bir türdür. Dramatik metinlerin yazılmaya başladığı tarihler, Yakın Doğu'da ve Uzak Doğu'da Avrupa etkisinin ışığında yorumlanabilir. Halk tiyatrosunun metinsel boyutu "dramın öteki tarafı"nda yer almaktadır. Bu durumda da dram kavramının tiyatro için yazılmış metinlerin tümünü bünyesinde toplayacak genişlikte, bir üst kavram olarak kullanılmasının anlamsal bir karşılığı kalmayacaktır. Bir alt tür olarak dramın tarihini doldurmuş olması, hiçbir biçimde tiyatroda metinden vazgeçildiğinin bir göstergesi

\footnotetext{
${ }^{1}$ H. T. Lehmann, "Theater der Blicke: Zu Heiner Müllers Bildbeschreibung”,
} Dramatik der DDR, (hrsg.U. Profitlich), Frankfurt /M, 1987., s. 186 
değildir; değişen tiyatro anlayışına uygun metinler yazılmaya devam edilecek ve bu metinler, "yazarın niyetinin öteki tarafına" geçerek, kendi tanım ölçütlerini sahnenin ölçütleriyle birleştireceklerdir. Pavis'nin Jean-Marie Piemme'den aktardığı şu sözler, tiyatroda metnin yeni konumunu anlatır niteliktedir:

Metin dönüş yapıyor, evet, ancak sürgünü boyunca, fetiş, kutsallaştırılmış, buyrukçu nesne olma kasıntısı azalmıştır. Bizi bugün eski hortlaklarından kurtulmuş olarak sorguluyor, sadakatin ve ihanetin ikili terörist yüzünün ona yaklaşmayı yönetmesine artık izin vermiyor. ${ }^{1}$

Dramatik metinlerde öznenin, eylemin, dilin yarattığ kuşkulara paralel gerçekleştirilen değişimler de, sanatın ait olduğu çağın ve toplumun duyuş-hissediş biçimleriyle ilişkisinin, organik bir ilişki olduğunu göstermektedir. Her çağın algılama biçimi tiyatro kavramına kendi algısının içerimlerini yüklemektedir. Antik çağın dinamikleri tragedyayı bir kurban ayininden rafine ederek türleştirirken, türe kendi mührünü basan antik kültür bir başka zamanda tekrarlanamayacağ 1 için tragedya da onunla birlikte yok olacaktır. Fakat bu yok oluş, yinelenemezlik, anın geri döndürülemeyişi düzlemindedir, Lehmann'ın "dramatik öncesi" adını verdiği tragedya metinleri, tiyatroda kullanılmaya devam edecektir. Benzer biçimde dramatik formu olanaklı kılan tarihsel olanaklar, hem felsefi hem de tiyatro anlayışı düzleminde sorgulanır hale gelmiştir, dolayısıyla dramatik form, artık belirli bir zamana ait oluşun işaretini taşımaktadır. 
Dramatik formu, sorunsuz bir biçimde kullanan yazarların varlığı da bu değişimi ortadan kaldırmaz ve postmodern düşünce onlara eski ve yeni biçimlerin biraradalığ 1 içinde bir yer belirler, bu yer ise uzun zamandır yapıt fikrine ait kuşkularla belirsizleşmiştir.

Postmodern dönemde tiyatro metninin,

ne diyalogların ayrıcalıklı ve 'tiyatro' kokan bir bütünü, ne Brechtçilerin hiç sıkılmadan istediklerini alabilecekleri bir inşaat malzemesi, ne de kuşkusuz, anlatılan olayları düşleyen bir okuyucu tarafindan okunan bir roman metni ${ }^{2}$

olarak algılanmadığını söyleyen Pavis, yeni sahneleme anlayışının metni, "artık, edimlerin ve karakterlerin, uzamın ve zamanın psikolojik ya da toplumbilimsel bir çözümlemesine bağlı olarak" ${ }^{3}$ ele almadığını belirtir. Artık metinlerin klasik ya da modern olması değil, sahneleme biçimleri önem kazanmıştır:

Metin, modern ya da klasik olsun, anlamından ve öncelikle dolaysız mimetik anlamından, yalnızca uygun bir sahnesel anlatım bekleyişi içinde önceden orada olan bir gösterilenden boşaltılmış gibidir. ${ }^{4}$

Pavis'nin postmodern tiyatroya ilişkin yaptığ 1 saptamaların özellikle tiyatro metinlerine yönelik bölümleri, yeni sahneleme anlayışına ayrımsız tüm metinlerin uyarlanabileceğini ifade

${ }^{1}$ P.Pavis, 1999,. Ön.ver., s. 60

${ }^{2}$ a.g.e. s. 96

, a.g.e.s. 96

${ }^{4}$ a.g.e., s. 96 . 
etmektedir. Çünkü "artık kendini yorumlanabilir bir metin ya da gösterim olarak değil, başkaları arasında dilsel metni de içeren göstergelendirici bir pratik olarak" ${ }^{1}$ sunmaktadır. Kendini sahneye uyarlamış metinler, "birbiriyle çelişen, birbirine yanıt veren ve sonunda tek bir küresel anlama indirgenmeyi reddeden anlamlar dizisi olarak algılanır." ${ }^{2}$ Anlamın çoğulluğu korunurken, amaçlanan "anlamın iletilebilirliği" olmayacaktır, "dilin kendi içindeki umarsız 1şık geçirmezlik" anlamın aslında sonsuza dek kaybolduğu bir algılama biçiminin işareti olarak yeni metinleri belirleyecektir. Fakat burada söz konusu edilen, absürd tiyatrodaki gibi anlamın yadsınması değildir. Anlamın yadsınması da, eskiden "anlam uyandırması gereken tutarlıl1k ve birliğin aynısına uymak" demektir. Çünkü absürd tiyatroda saçmanın hala bir anlamı vardır. Pavis, Adorno'nun absürd tiyatroya ilişkin yaptığı bir tespiti aktarır:

Absürd tiyatronun bile en yüksek düzeydeki temsilcileri arasında, hiçbir anlamın varolmadığını kendi içinde ereksel olarak düzenlenmiş bir anlam tutarlılığıyla dile getirmesinden dolayı diyalektikle ilişkisi vardır. ${ }^{1}$

Absürd sonrası yazarların pek çoğu için sorun "diyalogla monolog, iletişimle kakafoni, anlamla anlamsız arasındaki tartışma değildir"; yeni tiyatro biçiminde sözün kendisinin yeniden "edim" olması söz konusudur. Seyirci kitlesine bütün olarak seslenir, dinleyicilerin canları isterse alıp istemezse bırakacakları, olanaksız bir

1 a.g.e., s. 96 .

2 a.g.e. s. 97 
birleşik uzamın arayışı olarak "yüzlerine fırlatılan" bir şiir gibi. Tiyatro diyalog öncesi döneme dönmek ister, "en eski sahnesel biçimlerde" olduğu gibi. Peter Handke'nin, Bernard Maria Koltes'in ya da Heiner Müller'in metinlerinde "iletişim halinde ya da anlaşılmaz sözlere gömülmekte olan" konuşmacılar yer almamaktadır. Ulaşılan noktada "metnin ve anlamın çözümleri dizisi tüketilmiştir." Göstergelendirici bir pratiğe dönüşen tiyatro, "yorumlanabilir" bir metin ya da gösterim değildir, tümünü kendi pratiğinde birleştirmiştir. Göstergelendirici bir pratik, metin ve sahneleme arasındaki çatışmanın en az düzeye indirildiği bir çözüm olarak kavranabilir. "Metin soruların nesnesi, kodların çalışması olarak korunur, olaylar ve seyirciye duyumsatılması gereken altmetne anıştırmalar dizisi olarak değil."² Metindeki çelişkiler tek bir anlama indirgenmeyi reddeden bir çoğul anlamlar dizisine işaret ederler. Bu noktada yorum düşüncesi eski anlamını yitirir. Peter Brook, büyük metinlerin biçiminin sonsuza uzanan yorumlara açık, hiçbir yorumda bulunamayacak kadar ve bilerek olabildiğince belirsiz bir biçim olduğunu söyler. Teatral anlam, seyirci için bir üretim süreci olarak tanımlanır. Andrezj Wirth bu bağlamda Robert Wilson' un tiyatrosundaki değişimin "yorum" dan "yorumsamaya(hermeneutik)" bir değişim olduğunu belirtir. ${ }^{3}$

Dramatik temsilin mekanı olan tiyatro anlayışı terk edilmiş, tiyatronun kendi mekanizmaları ve koşullarından yararlanılarak oluşturulan eleştirel-analitik bir tartışmanın mekanı olduğu

\footnotetext{
a.g.e. s. 93

2 , a.g.e. s. 96-97.

${ }^{3}$ G. Poschmann, 1997., Ön.ver. ,s. 46
} 
bildirilmiştir. $\mathrm{Bu}$ noktada tek bir anlama bağlanan yorum olanaksızlaşır, çünkü gösterimin alımlayıcısı olan topluluk benzerliklerden değil farkl1lıklardan oluşur ve sahnedeki söylemde, çok katmanlı rüya yapısında olduğu gibi topluluk üyelerine tekil fantezilerin kapısı aralanmalıdır. Rüya için geçerli olan "resimler, devinimler ve sözcükler" arasındaki geçişkenliğin herhangi bir unsuru diğerinden üstün kılmamasıdır. "Rüya düşüncesi" de bir metin oluşturur ve bu metin, kolaj, montaj ve fragmana benzer, fakat bu düşünce olayların mantıksal akışını belirlemez. Gerçeküstücülerin miras1 olan rüya benzeri sahnelerin en önemli özelliği de herhangi bir hiyerarşi barındırmamasıdır. "Nasıl ki rüya göstergenin değişik bir kavrayışını gerekli kılıyorsa, yeni tiyatroda da anlam, "iptal edilmiş" bir göstergeye ve "unutulmuş" bir açıklamaya bağlıdır. ${ }^{1}$

Marianne van Kerkhoven, yeni tiyatro dili ile kaos teorisi arasında bir bağlantı kurmaktadır. Realite, kapalı bir daireselliğin içinde değil, kararsız sistemlerden oluşmaktadır. Önceden bütünün bir örneği olarak sunulan parça, artık tek anlamlı olmayanla, çok uyaranlılıkla ve eşzamanlılıkla kararsız sistemlerden birini oluşturacaktır. Yapının parçası kendi içinde bir bütünlük gibi geliştirildiğinde ise bu, eskiden olduğu gibi önceden verilmiş bir düzenin örneği ya da diğeriyle birleştiğinde oluşacak anlama bağlı bir simgesel işaret değildir. Artık hiçbir bireşim (sentez) gerçekleşmemektedir. ${ }^{1}$ Yorum yorumsamaya dönüşmüş, bireşim, parçanın bütünden kaçışıyla ortadan kalkmıştır. Organik bütünlüğü

${ }^{1}$ H. T. Lehmann, 1999., Ön.ver., s. 261 
reddediş, aşırı olana eğilim, deformasyon ve paradoksla birleşen yeni tiyatroda, birbiriyle bağlantısı koparılmış parçalar arasındaki ilişkininya da kopukluğun- seyircinin algısını kışkırtacağı ve fantezi gücünü aktif hale getireceği varsayılır. Çünkü insanın, duyu organlarının ilişkisizliğine katlanmasının güç olduğu ileri sürülür, tüm bağlantıları çözülmüş bir görüntünün karşısında seyirci, benzerlikler ve bağlamlar arayacaktır. Yeni tiyatro, rüya resimleri, hiyerarşik olmayan tiyatro gereçleri, eşzamanlı kullanılan göstergelerle yeni bir iletişim ortamını gerekli kılmaktadır. Tiyatro metinleri de bu sürecin bir parçası olarak ve daha da önemlisi bu sürecin kabulüne dayalı dilleştirmeyle, yollarını geçmiş dramatik metinlerden ayırmaktadırlar. "Yapıtın, tarih sonunun, hümanizmanın sonunun-Schechner'in dediği gibi- ya da Foucault'nun görüşüne göre "denizin sınırında kumdan bir yüz gibi silinecek" olan insanın sonunun, bir geleneği ya da mirasıyla olan göbek bağının kesilmesinden söz edilmiştir." ${ }^{2}$ Gelenekle bağı kopmuş metinlerde "kontur"larını yitirmiş insanın toplumsal-tarihsel bir açıklamayla tarihselleştirilmiş bireyle ilgisi kalmamıştır. Fakat absürd tiyatroda olduğu biçimde de kavranmamaktadır. "İnsan, daha çok bir söylem taş1yıcısı/değiş-tokuşçusu, teatral bir durumun gerçeğe yakınlığına boyun eğmeyen bir metin-söyleme makinası olmuştur." ${ }^{3}$

Postmodern tiyatronun ve rejinin anlamay1 "durduran" ve alımlamayı "kesintiye uğratan"4 ileri biçimleri, anlamın taşınmadığını

${ }^{1}$ G. Poschmann, 1997. Ön.ver., s. 45

${ }^{2}$ P. Pavis, 1999. Ön.ver., s. 103

3 a.g.e., s. 103.

${ }^{4}$ G. Poschmann, 1997., s. 36 
göstermişlerdir, anlam oluşum sürecini, meta-tiyatro olarak nitelenen ve dramın anlam sıkıntısını yansıtan bir noktaya taşımışlardır. Teatral pratik gösterenlerin pratiği olarak kabul edilince daha önce de belirtildiği gibi, sahnelenen metnin çok katlı anlam potansiyelini görünebilir k1lacak, yorumu reddedecek ve anlamın çoğulluğunu koruyacaktır.

Postmodern tiyatronun ve çağdaş reji anlayışının, anlam ve alımlamanın eski uzlaşımlarını kesintiye uğratan uç biçimlerinin ortaya çıkardığ 1 şudur: Anlam taşınmaz tersine anlam oluşum süreci meta-tiyatro olarak nitelenen bir noktaya taşınır ve bu noktada da dramın anlam sıkıntısı göz önünde bulundurulmaktadır. Meta-tiyatro geleneksel temsilin anlamına yönelik kuşkuların büyüdüğü bir noktada durmaktadır. Teatral pratik gösterenlerin pratiği olarak kabul edilince -önceden de belirtildiği gibi- sahnelenen metnin çok katmanlı anlam potansiyelini görünür hale getirmeye çalışacak, tek odaklı yorumu reddedecek ve anlamın çoğulluğunu koruyacaktır. Özne merkezini yitirdiğinden beri anlam da merkezini yitirmiştir; Derrida'dan daha öncede aktarıldığı gibi, "Anlamın çoğulluğu ya da istikrarsızlığı bir merkez, bir köken düşüncesinin dışlanmasıdır."1

Tiyatro metinlerinin tarihsel avangardlardan bu yana geçirdiği başkalaşım, tiyatro alanındaki arayışların nedensel altyapısını oluşturan düşünsel kırılmalardır. Bunun en temel sonucu "temsil krizi" olarak belirlenmişti. Temsil krizini yaratan kırılmanın ise gösterenlerle gösterilenler arasındaki uzlaşımsal birliğin kopmasıyla oluştuğu 
söylenmişti. $\mathrm{Bu}$ birliğin çözülmesinin ilk uygulamalarından birisi olarak sanatsal oluşumun materyal değerine yapılan vurgu, özellikle tarihsel avangardlarda karşımıza klasik temsil için araç olan unsurların, amaç olarak kullanılması biçiminde çıkarılmıştı. Bir öyküyü aktarmanın değil, aktarma biçiminin öne çıktığı gösterimlerin hedefi ise sahne dışı bir unsur olarak görülen öykünün karşısına sahne içi unsurları yerleştirerek tiyatronun özerkliğini vurgulamaktı. Bu vurgunun zaman içinde çoğalarak sürdüğü ve oyun yazarlarının da sahneyi ayrıcalıklı kılan bu çabalara sahnenin isterlerine uygun metin üretimiyle katıldıkları bilinmektedir. Bu çabalarla üretilen metinlerde s1k s1k metinlerarasılıktan, meta-tiyatrodan, ana metin yan-metin ayrımının ortadan kalktığından söz edilmektedir. Yeni tiyatro metinleri temel olarak bu teknikler dolayımında anlaşılabilmektedir. Örneğin metinlerarası yeni tiyatro metinlerinin önemli bir bölümünü açıklamakta kullanılabilecek bir terimdir. Geniş kullanım alanı düşünüldüğünde (alıntı, parodi, pastiş vb) metinlerarasıllk edebiyatta eskiden beri kullanılmaktadır. Fakat kavramsal düzlemde kullanımı ve yeni edebiyattaki rolünün ve işlevinin önemsenmesi anlamında görece olarak daha yenidir. Özellikle postmodern metinlerin ayırıcı bir özelliği olarak sunulan metinlerarası, bir "gösterenler zinciri”nde yakalandıkça elden kaçan anlam düşüncesini besleyen, yazarın ölümünü destekleyen bir yöntem olarak çağdaş metin çözümlemelerinde okurun karşısına daha sık çıkmaktadır.

${ }^{1}$ E. Sözen, 1999. s. 59 
1960'lı yılların yazın eleştirisinde, bir metin kuramı oluşturarak, metni tanımlamak ereğinde olan kimi eleştirmenlerin (özellikle Kristeva ve Barthes) girişimlerine sıkı sıkıya bağlı olarak ortaya çıkan metinlerarası kavramı, metnin özerk olduğu düşüncesi benimsendikten sonra, yaygın olarak kullanılan bir kavram olur. ${ }^{1}$

Metinleraras1, klasik metin düşüncesinin yazara bağlanan alanını, ayrışık unsurların yanyana geldiği bir "alıntılar mozaiğine" çevirecektir. Ve "postmodern söylemi (yazıyı) geleneksel söylemden (yazıdan) ayıran en temel özellik onun metinlerarasına yani farklı alanlara açılabilir olma özelliğidir." ${ }^{2}$ Postmodern tiyatroda da çok sesliliği yaratan yöntem metinlerarasıdır. Kristeva, Baktin'in "söyleşim" kavramından hareketle geliştirdiği metinlerarasını bir metnin tanımı için odak kabul edecektir: "Her metin bir alıntılar mozaiği gibi oluşur, her metin kendi içinde başka bir metnin eritilmesi ve dönüşümüdür." ${ }^{3}$ Umberto Eco kapalı metin yerine "açık metin"den söz ederken, "yazarın izleyiciye bitirilecek bir yapıt sunmadığını"1 söyleyecektir. Her metnin bir metinlerarası olduğunu söyleyen Barthes, metnin dili yeniden dağıtan bir üretkenlik alanı olduğunu bildirmektedir:

(...) metinde, pek çok bağıntı ağları vardır, biri ötekileri örtmeden aralarında oynarlar; bu metin bir gösterenler 'galaksi'sidir, bir gösterilenler yapısı değil; başlangıcı yoktur; geriye çevrilebilir; içine

\footnotetext{
${ }^{1}$ Kubilay Aktulun, Metinlerarası İlişkiler, Ankara: Öteki Yay., 2000., s. 7

2 a.g.e. s. 7.

${ }^{3}$ a.g.e. s. 41
} 
hiçbirinin ana giriş olduğunu söyleyemeyeceğimiz birkaç girişten ulaşılır; eyleme geçirdiği izgeler gözalabildiğince uzanır, karara bağlanamaz (anlam burada hiçbir zaman bir karar ilkesine uymaz, zar atılırsa o başka) $(. .)^{2}$

Metnin içine sokulan ayrışık unsurların metinde yol açtığ1 sonuçlardan birisi çok anlamlılık, çok seslilik ise diğeri de metni organik bir bütünlük olmaktan uzaklaştıran kolaj karakteridir. Tiyatro metinlerindeki en temel değişimin, kapalı, birlikli yapısını yitirerek kolaja, fragmana dönüşüm olduğu bilinmektedir.

Tiyatro metinlerinde ortaya çıkan bir başka sonuç da geleneksel dramdaki ana metin yan metin ilişkisinin geçersiz hale gelmesidir. Roman Ingarden'ın tanımına göre ana metin ve yan metin dramatik metni edebi metinlerden ayıran bir özellik olarak görülmekteydi. ${ }^{3}$ Bilindiği gibi oyun kişilerinin konuşmaları ana metni, konuşmaların dışında kalan bütün açıklamalarda yan metni oluşturmaktadır. Ana metin canlandırma ilkesine dayandırılarak oluşturulurken, yan metin sahnenin anlatısal işlevinin hesaba katılmasıyla oluşturulmuştur. Dilin dışavurum biçimi yanında sahnenin anlatım olanaklarına da işaret eden geleneksel ana metin/yan metin ayrımı aynı zamanda kurmaca içi teatralliğin(dramatik potansiyel ya da geleneksel teatrallik) de bir ifadesidir. Dramatik

${ }^{1}$ U. Eco, 1998., Ön.ver. s. 86

${ }^{2}$ Roland Barthes, Yazı ve Yorum, Çev. Tahsin Yücel, Metis Yay., 1999., s. 127

${ }^{3}$ Roman Ingarden, Das literarische Kunstwerk. Mit einem Anhang zu den Funktionen der Sprache im Theaterschauspiel, Tübingen, 1965., s. 411 
metinlerde var olan bu ayrım absürd metinlerde, Martin Esslin'in Dram Sanatının Alanı'nda, Godot'yu Beklerken'in son sahnesinde örneklediği gibi ana metin ile yan metin arasındaki çelişkiye dönüşecektir. Oyunun son sahnesinde ana metin: Estragon: "Evet, hadi gidelim" derken, yan metin: "Kımıldamazlar" demektedir. ${ }^{1}$ Klasik dramda yan metnin ana metin ile kurduğu ilişki tamamlayıcı bir ilişkidir; ikonik göstergeler sözel göstergeleri tamamlamaktadır. Beckett'in klasik dramla kurduğu negatif ilişkiyi somutlayan bir örnek olan bu çelişki yine de bir ana metin-yan metin ilişkisini, eleştirel bile olsa sergilemektedir. Yeni metinlerde bu ayrımın tümüyle ortadan kalktığı, metnin tek tabaka halinde sunulduğu görülmektedir ve böyle bir sunum da dramatik metin ile edebi metin arasındaki ayrımın iptali anlamına gelmektedir.

Metnin ana metin ve yan metin olarak birbirinden ayrilmas1, dramatik metnin canlandırma ve anlatısal olanla biçimlenen yapısal özelliğine dikkat çeker. Dram, belli bir mekanda ve belli bir zamanda figürler tarafından sürdürülen olayların gösterilmesi olarak tanımlanır ve böylece de temsil edici bir tür olarak belirir. Manfred Pfister, bir olay örgüsünün kendi yapısal unsurlarının-figür, mekan, zamanyardımıyla tanımlandığını söylemektedir. ${ }^{2}$ Bir olayı kurmaca biçiminde aktarma hem dramatik hem de anlatısal metinlerin ortak özelliğidir. Dramda söz konusu olanın anlatma değil, canlandırma olduğu bilinmektedir. Fakat metin aynı zamanda figürlerin dilsel

\footnotetext{
${ }^{1}$ Samuel Beckett, Godot'yu Beklerken, Çev. Tuncay Birkan, Kabalcı Yay., 1992., s. 96

${ }^{2}$ Manfred Pfister, Das Drama, Wilhelm Fink Verlag, 1997. S. 265
} 
olmayan eylemlerini de içermektedir ve simgesel metnin-dilsel-, sahnesel olanı da içermesi -dramatik potansiyel- iki metin katmanının var olma nedenidir. Dramda dilin görünüm biçimlerinin, konuşmacıya bağlı (monolog-diyalog) ve yan metin olarak ayrılması da bu içkinliğe işaret etmektedir. Dramda yaşanan krizin, bu kurmaca içi teatralliği (dramatik potansiyel) tümüyle ortadan kaldırmadığı söylenebilir. Dramatik form klasik tanımından uzaklaştığı durumda da, bir kurmacayı sahnesel olarak anlatmayı sürdürebilmektedir. Örneğin Beckett'in metinleri, bir temsilin olanaksızlığına işaret etse bile sözde konuşan figürleri sahneye getirir ve bu biçimiyle dramatiğe uygun bir kullanımdan söz etmek 'hala' mümkündür. Fakat bu imkan yalnızca form düzlemindedir. Beckett'in metinlerini dramatik formun eleştirel kullanımı çerçevesinde yorumlamak mümkündür. Beckett de az önce anılan ana metin yan metin çelişkisi kurmaca-içi teatralliğe eleştirel bir biçimde bağlanmaktadır ve ana metin yan metin çelişkisini bu bağlamda dramatik formun eleştirel kullanıldığı metinlerin bir özelliği olarak saptamak mümkündür.

Dramatik formun eleştirel kullanımı ile meta dram-tiyatro arasında bir bağ kurulabilir. Meta dram için en genel tanım ölçütü, özyansıtmadır. Öz yansıtmada dramatik ileti uzlaşımsal bağlarından koparılır ve iletinin estetik karakterine bir vurgu yapılır. Gösterilenlerin tümüyle kurmaca olduğunun altını çizen kurmacaya ait meta dramda, yansitmanın nesnesi dramdır. Bu yansitma kurmacayı desteklediği gibi, kırılmaya da yol açabilir. Poschmann'ın aktardığına 
göre, Richard Hornby, belirli anlamda her dramın meta dram olduğunu savunmaktadır. ${ }^{1}$ Çünkü her tiyatro metni, dramatik formun yapısını ve etki araçlarını kullanarak dramatiği estetik araç olarak anlamlandırmaktadır. Meta dram, öz-yansıtma nesnesi olan dramın unsurlarına zorunlu olarak bağlıdır; başka bir deyişle meta dram, eğer dramın kendisini konu etmesi olarak tanımlanıyorsa, dram zaten her durumda kendini konu etmektedir. Her tiyatro metni estetik araç olarak tiyatroyu kullanmak zorundadır.

Poschmann'1n belirttiğine göre, Vieweg-Marks ise, kurmaca kişilerin dilsel ifadelerindeki öz yansıtma ile tiyatronun bir içerik unsuru olarak dramda konu edildiği öz yansitmayı birbirinden ayırmaktadır. ${ }^{2}$ Gösterilenlerin tümüyle kurmacaya ait olduğuna vurgu yapan meta dramda, yansıtmanın nesnesi dramdır. Dolayısıyla meta dram figürlere bağlı olabileceği gibi kurmacaya da bağlı olabilir. Tiyatroda tiyatronun kullanımı çeşitli biçimlerde mümkündür: Dramı tiyatroda kendi konusu haline getirme ya da kurmaca düzlemi bir düş parçası olarak sunma. Estetik fenomen olarak tiyatro, alımlamanın ikili karakterine bağlıdır. Tiyatroda dramı konu edinen metinlerde, tiyatronun oyun niteliğine, kurmaca niteliğine dikkat çekilir ve seyirci dramın oyun karakterini alımlarken de yanılsama yoluyla bu bilgi yok edilmeye çalışılır. Tiyatro metinleri kullandıkları aracın bu çifte özelliğini hesaba aldıkları için meta dramatiktir. ${ }^{3}$

\footnotetext{
${ }^{1}$ G. Poschmann, 1997. Ön.ver., s. 96

2 a.g.e. s. 95

3 a.g.e., s. 97
} 
Meta dram bir teknik olmanın dışında, Helmar Schramm'ın gösterdiği gibi dünyayı algılama biçimine de bağlıdır. " "Metaforik model" olarak tiyatro, dünyanın bir tiyatro olarak algılanmasına bağlı geliştirilmektedir. İnsanı Tanrının bir oyuncağı olarak gören bu anlayış Platon'a kadar geri götürülebilir. Platon'da tanrı ve insan arasındaki ayrım, insanın tanrının bir oyuncağı olması ile verilmektedir. 16. yüzyılda dünyanın bir tiyatro olduğu düşüncesi yeniden güçlenmiş ve Barok dönemde "dünya tiyatrosu" metaforu sanatta bir üslup oluşturacak kadar genişlemiştir. Barok çağda yaşam, insani duygularla kavranamayacak, geçici bir yanılsama olarak görülmüştü. Dünyanın anlamsal imgesini ise sahne oluşturmaktaydı. Calderon'un "büyük dünya tiyatrosu" benzetmesinde, sahne kozmosun, dünyanın ve toplumun bir imgesidir. En tepede Tanrı oturmaktadır ve hazırladığı oyunu yönetmekte ve insanlara dünya sahnesindeki rollerin dağıtmaktadır. Dünyanın bu biçimde algılandığı bir düzlemde, tiyatro sahnesinde rol yapanlar kendi oyunlarını oyunun oyunu olarak niteleyeceklerdir. Oyun içinde oyun, dramın kapsamı dışındaki bir algı biçimine bağlı olarak gerçekleşmektedir ve oyuncunun oyunu seyircinin bilincinde çifte bir kırılma sağlayacaktır. Tanrısalın nesnesi olan oyuncu, temsildeki rolün taşıyıcısı aynı zamanda insani varoluşun anlamsal imgesidir de. ${ }^{2}$

\footnotetext{
${ }^{1}$ Helmar Schramm, "Theatralitat und Öffentlichkeit.", Asthetische Grundbegriffe. Studien zu einem historischen Wörterbuch, (hrsg.K.Barck, M.Fontius, W. Thierse), Berlin, 1990., s. 202-242

${ }^{2}$ H. Schramm, 1990, s. 206
} 
Dünya ve insani yaşam tıpkı tiyatro gibi göstergelerin bir bağlamı olarak kavranıp kurulurlar, tanrısal düzeni işaret eden ve sonsuz kutsal anlamı yorumlatacak göstergelerin bir bağlamı olarak. ${ }^{1}$

Dünyanın kurmaca karakteri kazandığı Barok dönemde, tiyatronun kurmaca karakteri zorunlu olarak meta bir düzlemdedir.

Shakespeare'de de tiyatro metaforu kullanılmaktadır, "bütün dünya bir sahnedir"² sözü, bir kurmacanın(dünyanın) içindeki güçlerin konu haline getirilmesini hedeflemektedir. Gerçeklik ve yanılsama arasındaki gerilimin işlevi ise dünyanın yanılsama karakterinin temsil edilişini açığa çıkarmaktadır. Temsil, aynı zamanda tiyatroyu bir mekan olarak kurmaktadır: Oradaki roller oyununda yeni kimliklerin oluşmasının gösterildiğini gösteren bir mekan. Seyirci oyuna, teatral bir yanılsamanın yaratılması yoluyla katılacaktır ve bu estetik etki metinlerde, oyun içinde oyunla, sunum düzleminin dramatik içi temalaştırılmasıly ya da oyuncu ve rolünün ayrılmasının yansıtılmasıyla sağlanmıştır. ${ }^{3}$ Fakat Shakespeare'de tanrısal düzen tasarımı Barok dönemdeki kadar sağlam değildir, Rönesans’ta gelişecek özerk birey kavramının öncü biçimlerine sahip olan Shakespeare'de, rol kişisinin eylemi tümüyle tanrısalın nesnesi kılınmadığı için bu tasarım ciddi bir kırılmaya uğramıştır.

\footnotetext{
1 a.g.e., s. 206

${ }^{2}$ W. Shakespeare, Size Nasıl Geliyorsa, çev.Bülent Bozkurt, Remzi Kitabevi, 1996, s.65

${ }^{3}$ H. Schramm, ön.ver., s.206
} 
Schramm'a göre dramatik dünya, meta dramatik yansitma sayesinde dünyanın öznel deneyiminin ve algılanma biçiminin gösterildiği bir araçsallık özelliği kazanmaktadır. ${ }^{1}$ Daha önce de belirtildiği gibi, dramın ve tiyatronun öz yansıtımı, kurmacayı desteklediği gibi yıkabilir de; hem dram içi hem de dramı aşarak gerçekleşebilir. Meta dram eğer dramatik formun eleştirel kullanımı için bir araç olarak kullanılıyorsa, buradaki öz yansıtmanın, sahnesel anlatım biçimi olan temsilin temelini eleştiriye açması gereklidir. Kendine gönderme yapan bu süreç, gösterilenlerin kurmaca karakterine dikkat çekerek seyircinin kurmaca dünyayla ilişkisini yabancılaştıracaktır.

Dramatik öz yansıtmanın dram içi kullanılmasına örnek olarak Hamlet metnindeki ünlü oyun içinde oyun verilebilir. ${ }^{2}$ Burada kurmacanın içinde tiyatronun araçları konu edilmektedir fakat bu meta dramatik düzlem tümüyle kurmaca içinin anlamına bağlı kalınarak oluşturulmuştur. Seyirci metnin içsel açılımlarından uzaklaşmadan oyun içinde oyunu izlerken, oyun kişisi de bu araç sayesinde kuşkularını yok etmek ya da anne ve amcanın kendi öykülerine verecekleri tepkiyi görmek gibi tümüyle dram içi bir yönelim içindedir. Oysa meta dramın eleştirel bir amaçla kullanılmasında, seyirci teatral öz yansıtma yoluyla dramın dışına çıkarılır ve yanılsama ile yanılsamanın bozulması oyununu doğrudan konusu haline getirir. Burada kurmacanın ve gerçekliğin sınırları

1 a.g.e, s. 228

${ }^{2}$ W. Shakespeare, Hamlet, çev. Bülent Bozkurt, Hacettepe Üni.Yay., 1982., s. 68 
belirsizleşecek, seyirci kuşkulu bir noktaya yerleştirilecektir. Metadram tekniğini bir tür yapı bozum tekniği olarak görmek mümkündür, gerçeklikle çatışma, sanatı "karşı kurmaca"ya doğru ilerletirken aynı zamanda bu çatışmayı, tiyatronun ve dramın çatışması haline getirmektedir.

Meta dram klasik metinleri yapı bozuma uğratma yöntemlerinden birisi olarak, klasik metnin gerçeklikle kurduğu ilişkiyi sorunlu bir zemine taşıyacaktır. Meta dramın, dramatik formu eleştirel olarak kullanmanın bir aracı olarak görmek gerekmektedir. ${ }^{1}$ Poschman'a göre meta dramı benzer biçimde, dramatik formun eleştirel kullanımı için araç olarak kullanan iki farklı tiyatro modeli vardır. Epik tiyatro ve Absürd tiyatro. Birbirinden farklı anlatım araçlarına sahip, bu iki tiyatro modelini ortak kılan dramı kendi araçlarını konu ederek yapıbozuma uğratmalarıdır. Klasik temsil araçlarının hem epik hem de absürd tiyatroda kullanıldı $\breve{g}_{1}$ bilinmektedir. Fakat bu kullanım eleştirel bir ton taşır ve her iki model de temsili, temsil nosyonunu yadsımak için kullanmaktadır. ${ }^{1}$ Dramatik temsile ait olan canlandırma ve anlatma, epik tiyatronun da araçlarıdır, canlandırma ve anlatmanın dramatik biçimde kullanımı yapıbozumuna uğratılmıştır: Epik tiyatroda şarkılar, bölüm başlıkları, projeksiyonlar bir yandan temsilin bir parçası olarak görünürken, diğer yandan hedefledikleri kurmacanın iç iletişim dizgesini kırmak ve yöneldikleri uzamın dış iletişim sistemi olduğunu vurgulamaktır. Klasik dramdaki olay örgüsü, yazarın müdahalesi ile anlatılan öyküye

$\overline{{ }^{1} \text { G. Poschmann, 1997. Ön.ver., s. } 96}$ 
dönüştürülmüştür ve bu öykü ancak dış iletişim sistemindeki alımlamayla bütünleştiğinde epik model amacına ulaşmış olacaktır. Dramatik temsilde iç iletişimin organik bir parçası olarak görülen canlandırma ve anlatma, epik tiyatroda "üst bir düzenlemeye ait olarak görünen etkileme taktiğinin" ${ }^{2}$ hizmetindedir. Kurmaca bir dünyanın özerkliği, kendine yeten oluşumu, kapalılığı yeniden üretilmez, tam tersine engellenir. Bir öykü anlatmaya dikkat çeken ve yanılsamayı yok etmeye çalışan ve iç kurmacanın anlamını seyircinin zihninde oluşturmayı deneyen epik tiyatro, klasik temsilin anlamı, bir gösterilene bağlayarak oluşturan kurmaca içi teatralliğini kırarak teatral sunumun öz yansıtımına yönelir. Bir öykü anlatılır fakat anlatılan öykü, dış araçlarla yorumlanır, "göndergesel yanılma" yok edilerek, oyundaki olayların seyirci tarafindan bir kurmaca olarak algılanması sağlanır ve sahnede olanların başka türlü olabileceğine işaret eden her düzenleme epik tiyatronun varlık nedenini diş iletişim sistemine bağlayacaktır. Dolayısıyla epik tiyatroda sadece anlatılan öykü değil, anlama sürecinin ve algının da öz yansıtımı önemlidir. Bir kurmaca klasik dramda olduğu gibi kendi içinde bir amaç olarak algılanmaz, bir başka amaç için araçsallık özelliği kazanmış olur. Bu biçimde de kurmaca araç haline gelmiş ve meta dramatik bir yöntemle dramatik yapının unsurları eleştirel bir düzleme kaydırılmıştır. Örneğin Kafkas Tebeșir Dairesi'nde bir masal anlatılır. Masalın anlatılma gerekçesinin dış çerçevesini ön oyun belirlemektedir. Temsilin şimdisine ait ön oyunda, vadinin paylaşımı tamamlandıktan

\footnotetext{
${ }^{1}$ a.g.e., s. 95
}

2 a.g.e. s. 95 . 
sonra, iç kurmaca, ozanın anlatacağı bir öykü olarak takdim edilir. ${ }^{1}$ Oyun içinde oyuna geçiş, bir tür tiyatro içinde tiyatro aracının kullanılmasıyla gerçekleşmiştir. Bir oyun oynanacaktır; bu bilgi zaten bir oyun olan ön oyunun kurmaca statüsünü yabancılaştırır. Çünkü iç oyun, ön oyunun oyuncularını seyirci düzlemine taşımaktadır. İç oyunda anlatılan öykü, klasik temsilin canlandırma aracından da yararlanır fakat Ozan'ın varlığı, kurmacanın kendi iç amaçlarına uygun gelişmesini engelleyecektir. Sahne başlıkları da temsilin kapalı kodlarını iptal etmektedir. Gruşa'nın öyküsü canlandırmanın araçlarıyla aktarılır fakat anlatının şimdisine bağlı Ozan'ın, anlatının geçmişine bağlı unsurlara şimdideki varlığını koruyarak seslenmesi ve örneğin Gruşa'nın 'anlatılan' oluşuna vurgu yapması ile klasik temsil imkansız kılınır. Metinde temsilin iç kodlarının kırılmasına örnek olabilecek pek çok sahne vardır fakat bu sahnelerden en önemlisi, Kuzey Dağlarına Kaçış episodundaki, Gruşa'nın soylu bebeyi bir köylünün kapısına bıraktığı sahnedir. Gruşa çocuğu bırakır ve kadının çocuğa sahip çıktığını görünce gülerek ters yöne doğru yürür. İşte bu noktada, Ozan öykülediği kişiye doğrudan seslenir: "Niye böyle şensin, evine gidiyon diye mi kardeş?" ${ }^{1}$ Fakat Gruşa cevap veremeyecektir, çünkü anlatı kipleri farklıdır. Epik tiyatroda klasik temsilin unsurları, klasik temsilin olanaksızlığını kavratacak biçimde kullanılmıştır.

Dünyanın gerçekliğini yansıtmak amacını taşıyan klasik temsil, gerçeklik algısındaki değişim sonucu kırıldığında dramatik

\footnotetext{
${ }^{1}$ Bertolt Brecht, Kafkas Tebeşir Dairesi, Çev.Can Yücel, İzlem Yay., 1980
} 
metinlerdeki gerçeklik düşsel bir biçim almış ve bilinçaltı gerçeğinin yansıtılması, dışsal dünyanın yansıtılmasından daha önemli hale gelmiştir. Bilindiği üzere geleneksel rüya oyununda (Strindberg) rüya sahnelerinin işlevi gerçeklik algısındaki değişimi yansıtmaktı. Poschmann, Richard Hornby'nin absürd meta dramı, geleneksel rüya oyunu tasarısının, genişletilmiş bir çerçevede sunumu olarak yorumladığını aktarmaktadır. ${ }^{2}$ Rüya oyunu yazımında, rüya sahneleri metinde parçalar halinde bulunur ve anlatının düzlemini bir başka gerçeklik algısına taşır. Temsilin klasik akışını kesintiye uğratan bu yapılaştırma, dram içi bir zeminde hareket etmektedir. Absürd oyunlarda ise eylem çerçevesi en aza indirilir, belirsizleşir ve tümüyle yok edilir. Klasik temsilde temel bir unsur olan eylem, absürd oyunlarda sadece bir düş niteliği yüklenmektedir. Fakat burada düş, gören özneden koparılarak, oyunun bütünü bir düş gibi sunulacaktır. Geleneksel rüya oyunu sahnesinde, kurmaca figürün bilinçaltı düşleri olarak beliren ve kurmacaya da bu biçimde dahil edilen düşler, absürd oyunlarda değişmiştir. $\mathrm{Bu}$ oyunlarda gerçeklik yansıtılmaz fakat gerçekliğe karşılık sunulan rüyalar da öznesinden koparılmıştır. ${ }^{1}$ Sahnedeki olaylar bütün yaşam deneyiminden soyutlanır, absürd yasaların düzenlediği bir başka iletişim çerçevesi kurulur. Hornby'nin çerçevesi genişletilmiş rüya oyunları ile söylemek istediği, verili gerçekliği tümüyle aşan bir sahnesel gerçekliğin rüya niteliğidir. Teatral iletişim sistemi geleneksel uzlaşımlarından koparılmıştır ve belirli anlamsal kodlara bağlı bir kurmaca zemini yok edilmiştir. Dil

${ }^{1}$ B Brecht, a.g.e. s. 47

${ }^{2}$ G. Poschmann, 1997. Ön.ver., s. 95 
mekanik ve oyunsudur. Absürd oyunlarda da dramatik anlam otomatik olarak algılanmaz, bir dolayıma yerleştirilir ve anlam, ancak alımlayanla bütünleştiğinde ortaya çıkacaktır. Anlam yitimini belgeleyen bu tiyatro modelinde de klasik temsilin canlandırma, diyalog gibi temel unsurları kullanılmaktadır fakat parodi biçiminde. $\mathrm{Bu}$ noktada absürd metinlerin meta dramatik yönelimi, dramın araçlarını parodize ederek-parodi aynı zamanda metinlerarası bir yöntemdir- dramı kendi konusu haline getirmesinde açığa çıkmaktadır. Parodize edilen bir öykü değildir; parodize edilen bir form ve onun tüm ilkeleridir. Beckett'de gerçeklik karşısında tiyatro durumunda temsil edilenlerin sıradanlığının vurgulanması doğrudan varolan, nesnel bir gerçeklik kuşkusunu ve böylelikle de onun temsilinin olanaksızlığı ifade edilmektedir. Temsilin araçları kullanılarak gösterilmeye çalışılan bir temsilin olanaksızlığıdır. Godot'yu Beklerken metninde Beckett bir oyunun anlamını ortadan kaldırmıştır; "gösterimin fizik koşullarının artık dışına çıkılmış, teatral varoluşun anlamı kendisi tarafindan azaltılmış ve sahnede figürlerin salt mevcudiyeti önem kazanmıştır." ${ }^{2}$ Gerçekliğin kaybolması temsilin imkansızlığına yol açarken, meta dramın kullanılması da dramatik formun imkansızlığını vurgulamak içindir.

Gerek epik gerekse absürd tiyatroda, artık odak olan bir kurmacanın sahnesel gösterimi değildir, tiyatronun öz yansıtımıdır. Farklı amaçlar için de olsa dramatik formu eleştirel bir biçimde

${ }^{1}$ a.g.e,s 95 ..

${ }^{2}$ Katherina Keim, Theatralitat in den spaten Dramen Heiner Müllers, Tübingen, 1988. S. 23 
kullanan bu iki tiyatro modelinin etkilerini çağdaş tiyatro metinlerinde de görmek mümkündür.

Meta dramın yapıbozucu uygulamasının klasik örneği olan Altı Șahıs Yazarını Arıyor, metninde kullanılan geleneksel oyun içinde oyun tekniği aslında dramatik tiyatronun gereklerine karşı yöneltilmiş dramaturjik bir saldırıdır. Oyunun eylemi, hem geleneksel temsilin karmaşık gerçekliği yansıtmasının imkansızlığıyla uğraşır, hem de Pirandello, iki oyun düzlemini içiçe geçirerek ikisinden sadece birinin, gerçek olarak tanımlanmasının imkansız olduğunu gösterir. "Gerçekliğin çok katmanlılığı" dramın problemi haline gelmiştir ve Freud'un bilinçdışı teorisinin yaygınlık kazanmasıyla "kurmaca meta dramın" en önemli somutlaması oyun içinde oyunla gösterilecektir. Fakat kurmaca özelliğin çifte katlanması, öznelliğin yoğun olarak öne çıktığı rüya sahnesi gibi kurgularda, bir meta düzlemde gerçekleştirilecektir. Bu sahneler-rüya sahneleri- seyircinin kurmaca ve gerçek arasındaki sınırlar konusundaki kuşkularını, sınırları ortadan kaldırarak çoğaltacaktır. ${ }^{1}$ Absürd tiyatronun rüya sahnesi mantığının genişletilmesi ve rüyanın özneden koparılarak oluşturulduğu söylenmişti. Bunun anlamı ise, yinelenecek olursa absürd tiyatro, meta tiyatronun dramatik düzlem ile düşsel bir meta düzlem arasındaki sınırların aşırılaştırılmış iptalinden başka bir şey olmadığıdır.

Yeni tiyatro metinlerinde tiyatronun konu olarak ele alınması aynı biçimde gerçeklik ve kurmaca arasındaki ayrıma yönelik kuşkuların bir ifadesidir. Tiyatroda, tiyatronun, dramın ve ona bağlı 
unsurların konu edildiği örneklerin tümünde klasik temsil anlayışının bir sorun olarak ele alınması ve sorgulanması söz konusudur. Örneğin Thomas Brasch'ın dilimize de çevrilen Kadınlar.Savaș. Komedi metni 1995 yılında basılmıştır. Bu metin kurmaca düzlemin çeşitli biçimlerde meta dramatik işaretlerle vurgulanmasını içerir. Oyun kişilerinin tanıtımı, "Rosa'yı Canlandıran Oyuncu" ve "Klara'yı Canlandıran Oyuncu" biçiminde yapılarak, temsilin kurmaca niteliğine dikkat çekilmiştir. ${ }^{2}$ Ayrıca metin Troilus ve Kressida ile metinlerarası bir ilişki kurarak dramatik bir metni de konusu haline getirmiştir. Metnin 2. Bölümü'nün başlığı "Troya Tiyatro Ölüm”dür, ve altındaki açıklama:"Kör Pandaros ve ona sur boyunca eşlik eden Suflör.(...)"13 biçimindedir. Suflörün girişi, tiyatro durumunu açıklayarak konulaştırır ve seyirciye yönelerek kurmaca içinden uzaklaşır. Metnin bütününde kullanılan oyun metaforu ise (Satranç oyunu, rol oyunu, aşk oyunu, tiyatro) gerçeklik ve kurmaca arasındaki sınıra işaret etmektedir. Oyun kişilerini canlandırdıkları vurgulanan figürler, alıntılarla konuşarak bu meta düzlemi sürdürürler: "KLARA'yı CANLANDIRAN OYUNCU: Eğer bize ihtiyaçları varsa Rosa, der Klara". ${ }^{4}$ Metin hiçbir dramatik olay örgüsü içermez, "kadınlar.savaş.komedi" temasının çeşitlemelerini sunar. Thomas Brasch geleneksel dramın yalıtılmış unsurlarını kullanır fakat belirleyicilikleri olmaksızın. Figürler vardır fakat canlandırıcılar

${ }^{1}$ G. Poschmann, 1997., s. 108

${ }^{2}$ Thomas Brasch, Kadınlar. Savaş. Komedi, çev.Sibel.A.Yeşilay, Mitos Boyut Yay., 2002., s. 13

${ }^{3}$ T. Brasch, a.g.e. s. 31

4 a.g.e. s. 20 
tarafından aktarılırlar. Replikler, sözde diyalogdan, alıntıdan başka bir şey değildir. Dramın bu yapıbozumunu yazar, dramatik-temsil edici tiyatronun öz yansıtımıyla bağlantılandırmıştır.

Dramatik biçimi sorgulayarak oluşturulan metinlerde, klasik temsil anlayışının araçsallaşması söz konusudur fakat bu metinlerde klasik temsilden geride kalanlar tanınabilmektedir. Klasik metnin yapısal bileşenleri geleneksel biçimde kullanılmadığında bile tümüyle ortadan kaldırılmamıştır. Çelişkili bile olsa ana metin-yan metin ayrımı korunmakta, görünüşte de olsa rol kişilerine bağlı diyaloglar sürdürülmektedir. Fakat dramatik biçimi tümüyle aşan örnekler, geleneksel metin bilgisinin sınırlarını zorlamakta ve eleştirel biçimde bile olsa dram kavramının kullanımını olanaksız kılmaktadırlar. Bu metinler canlandırmadan ve anlatımdan vaz geçmişlerdir, buna bağlı olarak ana metin ile yan metin arasındaki ayrım ortadan kaldırılmış ve metin tek bir katman halinde sunulmuştur. Repliklerin bir oyun kişisine bağlanmadan düzenlendiği metinlerde, dramın kişi, durum ya da eylem gibi unsurları tümüyle yok edilir ve tiyatro metninin malzemesi olarak sadece dil kullanılır. "Dilin sahnelenmesi" olarak tasarlanan bu metinler için Müller'in Bildbeschreibung (Manzara Tasviri) ya da Handke'nin Publikumsbeschimpfung (Seyirciye Sövgü) örneklenebilir. Müller'in metninde bedensiz bir ses konuşur, bir öykü anlatmaz, bir durum açılamaz, sadece bir manzarayı tarif eder. Handke'nin metni ise "dört konuşmacı" için yazılmıştır fakat metindeki konuşma, onlar arasında paylaştırılmadığı için kimin konuştuğu belirsizdir. Dilsel metin: "Siz oyun seyredemeyeceksiniz/ 
Bakma zevkiniz tatmin edilmeyecek/ Burada oynanmayacak/ Görüntüsüz bir oyun göreceksiniz" ${ }^{1}$ biçiminde sözlerle metnin canlandırmadan ve anlatmadan vazgeçtiğine işaret etmektedir:

$\mathrm{Bu}$ dram değil. Burada olmuş hiçbir eylem tekrarlanmayacak. Burada sadece bir şimdi ve bir şimdi ve bir şimdi var. ${ }^{2}$

Bir anlamda dramatik tiyatroya bir protesto olarak okunabilecek metin, tiyatronun kullandığı bütün araçlara arkasını dönmüştür. Aynı zamanda tiyatroyu kendi konusu yapmış fakat dramı aşarak kullanmıştır. $\mathrm{Bu}$ metinlerde dramatik tiyatrodan hiç iz kalmamış, dramı aşarak "öteki tarafi"na geçen bu örnekler tiyatro metinlerinin aldığı uç biçimi göstermektedir.

Dilin mevcudiyetine özel bir vurgu yapan metinler, sahnesel etkinin kendisine değil, dilsel malzemenin teatralliğine dikkat çekmeyi amaçlamaktadırlar. Dilsel materyalin kendisine yapılan vurgunun, dilin estetik işleviyle ilgili olduğu özellikle Roman Jakobson'un çalışmalarında ve Yapısalcı teoride ortaya konulmuştu. Özellikle Jakobson'un şiirsel işleve ilişkin yaptığı açıklamalar, edebi metinleri diğer metinlerden ayıracak bir ölçütün oluşmasına yol açmıştı. Şiirsel işlevi sanatın tek işlevi olarak görmeyen Jakobson, belirleyici bir unsur olduğuna dikkat çekmiştir: "Şiirsel işlev, dilsel sanatın tek işlevi değildir, yalnızca en belirgin, en belirleyici işlevidir; öteki dilsel

\footnotetext{
${ }^{1}$ Peter Handke, "Publikumsbeschimpfung", Die Theaterstücke, Suhrkamp Verlag, 1992. S. 12

2 a.g.e. S. 12.
} 
etkinliklerde ise ikincil, yardımcı bir öğe durumundadır." ${ }^{1}$ Şiirsel işlev, "bildirinin kendine dönük olması, bildirinin bildiri olarak odaklanması" ${ }^{2}$ biçiminde tanımlanmaktadır. Estetik işlev, gösterge ile göndergesi arasındaki toplumsal uzlaşımların sabitlediği anlamsal bağlantının otomatikliğini yok etmektedir; iletişim amaçlı dilin, ileti değerinden önce kelimenin somut varlığına dikkat çekerek verili anlamdan uzaklaşmasını sağlayacaktır. Kendi mevcudiyetine odaklanan dil, öz yansıtımlıdır ve bu biçimiyle de dilin çoğul anlamlılığına ulaşılacaktır. Dile özel bir vurgu yapan metinler, dilsel gösterenlerin edimsel(performativ) potansiyeli olarak anlaşılabilen metinsel teatralliği tiyatro için kullanmışlardır. ${ }^{3}$ Kurmaca ve gerçeklik ilişkisini sorun olarak ele alan ve anlam oluşumunun geleneksel süreçlerinin sorunsallaşmasının, tiyatroda meta dramatik yöntem aracılığıyla yansıtıldı $\breve{g} 1$ bilinmektedir. Bu tür metinlerde olup bitenler seyirci için kuşku yaratacak bir biçimde düzenlenirken, algının problem haline gelmesini anlaşılır kılma aracı olarak diyalog bir anlamda geleneksel işlevine yakın kullanılmıştır. Kurmaca içinde figürlerin konuşmaları olarak yer almayı sürdürürken, bir çeşit kurmaca dil anlaşmasının temsiline hizmet etmekte, kişiler arasındaki iletişimi bir biçimde kurmaktadır. Repliklerin özne bağlantısından koparıldığı bir noktada ise artık dili, anlatıcı figür konuşması olarak tasarlamak güçleşecektir. Yalnızca algının, anlamın ve gerçekliğin değil, öznenin kayboluşuyla dilin de sorun haline gelmesi onun meta

\footnotetext{
${ }^{1}$.Mehmet Rifat(Haz.), Dilbilim ve Göstergebilim Kuramlart, Yazko Üretim Kooperatifi, 1983., s. 55

${ }^{2}$ M.Rifat, a.g.e. s. 55 .

${ }^{3}$ G. Poschmann, 1997., Ön.ver. s. 100
} 
bir düzleme taşınmasına neden olacaktır. Özne merkezsizleşmiş ve söylem tarafindan düzenlenen bir şey haline gelmiştir. $\mathrm{Bu}$ durumda dil, öznenin ifadesi olarak bir araç olma özelliğini yitirir ve doğrudan kendini temsil eden haline gelir. Eğer özne "konuşulan" ise dil, insanı merkezden uzaklaştırıp yerine geçmeye çalışacaktır. "Kendi üstdilini öngören ve taşıyan bir dilin sözü" ${ }^{1}$ metinlerin oluşumunu etkileyecektir. "Anlatıda 'olup biten', göndergesel (gerçek) bakış açısına göre, sözcüğün tam anlamıyla hiçtir; "olagelen" yalnızca dildir" $^{2}$ sözleriyle anlatıyı tanımlayan Barthes, dili, özneyi aşan, kapsayan bir oluşum olarak nitelemektedir. Buradaki süreç de, tıpk1 rüya sahnelerinden absürd tiyatroya giden yola benzer bir biçimde kurulmuştur. Gerçekliğin katmanlı yapısını yansıtabilmek için tasarlanan rüya sahneleri, temsilin olanaksız olduğu absürd tiyatroda, rüyayı görenden kopararak, tüm oyunu rüya gibi sunarak, genişlemiş bir çerçeveye taşınmıştı. Benzer biçimde dil, yabancılaşmış öznenin ve onun algısındaki kırılmaların ifadesi olarak kullanılırken hala bir özneye bağlıdır fakat özneden koparıldığı noktada tüm metni kapsayacak kadar çerçevesini genişletecektir. Artık bir araç olarak değil, bir amaç olarak görülecek ve bu da tiyatro metinlerinde farklı biçimlerde kullanılacaktır.

"Tiyatro Oyunlarında Dilin İşlevleri" adlı yazısında Roman Ingarden, dram için dilin çifte anlam taşıdığını bildirmişti. ${ }^{3}$ Dramda

\footnotetext{
${ }^{1}$ Roland Barthes, Göstergebilimsel Serüven, Çev.M.Rıfat, S.Rıfat, YKY., 1993., s.112

${ }^{2}$ R. Barthes, a.g.e. s. 117

${ }^{3}$ Roman Ingarden, 1965
} 
dil hem iç iletişim sisteminde işlevseldir, hem de "ötekine yöneltildiği" için dış iletişim sistemini de kapsamaktadır. Pfister, dilin işlevlerini -Jakobson'a sadık kalarak- göndergesel, anlatımsal, bağlantısal, üstdilsel ve estetik olarak sıralamaktadır. ${ }^{1} \mathrm{Bu}$ işlevler içinde yalnızca estetik işlev, iç iletişimi aşmakta ve dış iletişime yönelmektedir. Kurmacanın içinde figürler arası iletişim aracı olarak kullanılmayan estetik işlev, kendine gönderme yaparak seyircinin alımlamasıyla bir anlam kazanacaktır.

Dilin saf oyun karakteri kazandığ 1 metinlerde, dil de "1şık, renk, resim, müzik ve sahnenin sözel olmayan diğer işaretleri gibi geleneksel anlatıcı işlevinden kurtulmuştur." ${ }^{2}$ Kurmaca bir olayın, kurmaca bir figürün betimleyici konuşması aracılığıyla aktarılmasının yerini, dilin çok-sesli söylem ya da monolog olarak kullanımında, konuşulanın saf materyal değerine yapılan vurgu alacaktır. Burada dilin kullanma biçimi, dramatik dili normal dilden ayıran ve dilin "sapma boyutu" olarak nitelenen dilsel kullanımdan farklı düşünülmelidir. Çünkü dilde sapma olarak nitelenen bu boyut, geleneksel kullanımda dramatik anlatıyı destekler ve anlatma ile canlandırmanın temsil edici ilkelerini ortadan kaldırmaz.

Estetik işlevin baskın bir biçimde kullanıldığı metinler, dil oyunu, alıntılar montaj1, dilin söylem karakterinin vurgulanması gibi postmodern estetiğe atfedilen özellikleri taşırken, tarihsel avangardların metin üretimindeki dil kullanımını sürdürdükleri

\footnotetext{
${ }^{1}$ M. Pfister, 1997., Ön.ver. s. 151.
}

${ }^{2}$ G. Poschmann, 1997., s. 180. 
söylenebilir. Yeni tiyatro metinlerinin dramatik formu eleştirel bir biçimde kullanan örneklerinde dilin, konuşma edimi olarak temsilin asal bir unsuru olmaktan uzaklaşmasının işaretlerini koro kullanımında, figürlerin alıntılarla konuşmasında ya da kimliklerinin numaralarla, harflerle belirtilerek silinmelerinde görmek mümkündür. Kişilerin anlamlı konuşmalarının yerine seslerin tiyatrosuna yönelen metinlerde figürler belirsizleştikçe sesler önem kazanacak ve bu tür metinler bir radyo oyunu gibi sadece işitsel unsurların dikkate alınmasıyla oluşturulacaktır. Çeşitlenen metinler manzarasında dilin bir "büyü" olarak kurulduğu ya da dilin özneden tümüyle koparıldığ görülecektir. Heiner Müller bir söyleşisinde özne ve dil ilişkisini şöyle yorumlar:

Ben hiçbir oyuncunun 'derin' oynarmış gibi yapmasını istemem. Oyuncular bir şeyler göstermeye kalkışmasınlar, sahnedeki oyunu yaşammış gibi oynamasınlar. Onlar hiçbir durumda konuşamazlar. Onlar 'konuşmama makinesi' olmalıdırlar. ${ }^{1}$

Dilin başat bir rol üstlendiği biçimlerden birisi olarak görülebilecek monodramlar, tek kişilik oyunlar olarak insanlar arası iletişime karşı kuşkuların ifadesini yansıtırlar. 18. yüzyılın sonunda biçimlenen monodram kavramı, klasik kullanımında oyun kişisinin ruhsal durumunu aktarmayı amaçlarken müzikle desteklenen, bildirim işlevine sahip bir dil kullanmaktaydı. ${ }^{1}$ Müzikle bağlantısı zaman içinde kaybolan tek kişilik metinler, bireysel dramlar olarak

\footnotetext{
${ }^{1}$ G. Poschmann, a.g.e. Ön.ver. s. 195
} 
nitelenmişlerdir. Dramatik bir durumla başlayan, bir olayı bir karakterin monologuyla aktaran monodramın değişimini hedefleyen yeni monodramatik metinler, konuşan bir özneden vazgeçerek, öznesiz bir konuşmayı yerleştirirler. Konuşmanın sessel değerlerinin öne geçtiği, bir öykü anlatmayı bırakan bu metinlerde, kurmaca bir dünya yaratmaktan vazgeçen hatta bir durumdan bile uzak duran yazarlar, dramın "öteki tarafi”nda konumlanacaklardır.

Tiyatro metni Kristeva'nın tanımladığı anlamda metne dönüşmektedir. Kristeva, "estetik dilin devrimini" dilin bir başarısızlığg olarak (çünkü işlevlerini terk etmiştir) kullanılmasında görmüştü. $\mathrm{Bu}$ devrim, dil ile bir gösteren sistemi oluşturarak "olası anlam potansiyellerini telaffuzda ve alımlama sürecinde" mümkün gören bir metinsellik oluşturmuştur. ${ }^{2}$ Tiyatro metinleri dilin estetik işlevi için yeni olanaklar ve boyutlar aramaktadırlar. Bu arayışlar dili, geleneksel eyleyen öznenin imleyicisi olmaktan çıkarmış ve bir iletişim aracı olmaktan uzaklaşmıştır. Artık dünyasal gerçekliğin yansıtılmadığı metinlerde dil, kendine gönderme yaparak dramatik tiyatronun temsil ilkesini de sorunsallaştırmıştır.

Dilin estetik bir bildiri olarak sunulduğu metinlerin bir bölümünde, kendi estetik boyutuna ve çoğul anlamına kilitlenen biçimler, sahne metnine doğrudan çevrilmeye direnirler. Bu metinler, yönetmen ve oyuncu için bir tür şifre yazımı olarak

\footnotetext{
${ }^{1}$ Manfred Brauneck, Gerard Schneilin, Theaterlexion, Rowohlts enzyklopadie, 1992., s. 622

2 J. Kristeva, 1978., s. 206
} 
değerlendirilebilirler. Şifreler ya da işaretler yönetmen tarafından yorumlanacak, ikinci bir yaratı sürecinden sonra sahnenin diline çevrilebilecektir. $\mathrm{Bu}$ tür metinler, sahnede gösterilecek, canlandırılacak olanı doğrudan açıklamaz, sadece sahnenin işaretlerini dikkate alan simgesel göstergeler oluşturur. Okumalar ve rejinin düşgücü için yeni anlamsal mekanlar açmayı hedefleyen bu metinler, söylendiği gibi içerdikleri şiirselliği sahnede yeniden yaratacak ikinci bir yaratıcılığı talep ederler. Metin bir tekliftir, potansiyel bir "değişim değeri"1 ${ }^{1}$ barındırmaktadır. Onun yarattığı imgelem, rejisör için klasik metnin sahnelenme çağrısının uzağındadır; rejisör metnin anlam olanaklarını sahnede yorumlayacaktır.

Dolaylı bir biçimde de olsa sahnesel anlamı şifreleyerek barındıran bu metinlerin yanında, dil dışı hiçbir teatral göstergeye aktarılamayacak metinler vardır: Performans olarak nitelenen bu metinler sadece kendilerine dikkat çekmektedir. Dil dışı göstergelerin dikkate alınmadığı bu, "sadece kendi için konuş(maktadır)-an" 2 metinler, "okuma tiyatrosu" için de anlam taşırken, sahne için bir anlam oluşturmaktan vazgeçmişlerdir. Çünkü artık anlam, "taşınan bir şey olarak değil, dilin estetik boyutunda üretilen bir şey olarak" ${ }^{3}$ görülmektedir. Konuşulan dilin tınısı, eklemlenmesi, müzikal etkisini kullanan bu metinler, tiyatroyu "oral oluşum" ve simgesel ile imgeselin kesişme noktası olarak gören anlayışın ürünleridir.

${ }^{1}$ G. Poschmann, 1997 Ön.ver.., s.253

2 a.g.e. s. 339

3 a.g.e. s.339 
Tiyatro metinlerindeki eğilimleri, değişimleri niteleyen kolaj, metinlerarasıl1k, meta-dram ve metinsel teatrallik gibi kavramların her biri diğeriyle iç içe geçerek bir anlam oluşturmaktadır. "Anlamın kaçış noktasını" konu haline getiren bu metinlerin genel görünümü kurmaca ve gerçeklik ilişkisinin değişimi altında daha belirginleşmektedir. Yeni metinleri oluşturan tüm bu araçlar, yöntemler tek bir şeye işaret ederler: Klasik temsil imkansızdır.. Klasik temsilin kaybolduğu, bütünlüğünü yitirmiş bir dünyada oyun yazarları, yitenden kalanları göstermektedirler. Metinlerarasılık, gidip geldiği metinler arasında bir bağlantı kurmayınca anlam oluşumunu bir montaja, her durumda da metnin yapısını bir kolaja dönüştürecektir. Bütünlügün yitişi, anlamın yok oluşu aynı zamanda öznenin deneyimin parçalanmasına, öznenin merkezsizleşmesine bağlıdır. Meta-dram tekniği temsilin problem haline geldiğini, kurmaca ve gerçekliğin sınırlarının yok olduğunu bildirmektedir. Referans alacağı bir gerçeklik kalmayan kurmaca, "suretlerin asıllarından gerçek oluşu" gibi, giderek karşı-kurmacaya dönüşecektir.

Geleneksel teatrallik, her şeye karşın bir dramatik potansiyele işaret etmektedir, onun kullanımından vazgeçen bir metin canlandırma ile anlatma arasındaki sınırları ortadan kaldırarak, dilin edimsel/performativ niteliğine vurgu yaparak yeni bir teatrallik oluşturmaktadır." Dil resimlerinden, dilin somut varlığından söz etmeyi olanaklı kılan metinler, rejinin ikonik göstergeleriyle diyaloga geçerek yeni bir dilleştirmenin peşine düşmüşlerdir."1 Şiirsel dile

a.g.e., s. 340 
yapılan aşırı bir vurguda dilin işlevsel kullanımı ufalanarak yok olacaktır. Bir öykü anlatmaktan vazgeçen metinler, teatral temsilin Aristoteles'ten Brecht'e kadar "kalbi" kabul edilen bir unsuru söküp atmışlardır. Anlatılar sona ermiştir artık tiyatronun ütopyası bir metnin içeriğine bakılarak anlaşılamayacak, yalnızca formundan çıkarılacaktır. Temsilin sonuna gelinmiştir, tarihsel avangardlarla başlayan "kriz", dramatik formu tarihsel olarak aşılmış bir "alt"model haline getirmiştir ve bu modelin kırık parçalarıyla oluşturulmaya çalışılan metinler, nedensel yapının, kendi dışına kapalı bir mutlaklığın zaman içinde nasıl dağıldığını örnekleyeceklerdir.

Yapısal kırılmaların büyük bir parçalanmaya neden olduğu günümüz tiyatrosunda dram artık tiyatronun "öteki tarafi", metin ise sadece "yabancı bir bedendir." Bütün bu gelişmeler tiyatroyu ve tiyatro metnini ortadan kaldırmamıştır; klasik bir formun zamanaşımına uğradığını belgelemiştir. Tiyatro metinleri çeşitli biçimlerde hala yazılmaktadır ve belki de kalıplarından kurtulduğu için daha özgür bir zeminde (bir zemin var mıdır?) durmaktadır. Bir deneyimin nesnel ölçütlerle sınanarak aktarılmasına inançlarının kalmadığını söyleyen metinler, klasik metinlerden daha zorlayıcıdır. Metinlerdeki radikal değişimlerin sahnedeki değişimlerin sonucu olduğu unutulmamalıdır. Tiyatro metinleri biçimsel olarak, türler arasındaki sınırları yok ederek edebiyata yaklaşırken, paradoksal bir biçimde de edebiyattan uzaklaşacaklardır. 


\section{KAYNAKÇA}

Aktulun, Kubilay. Metinlerarası İlişkiler, Öteki Yay., 2000.

Barthes, Roland. Göstergebilimsel Serüven, Çev.M.Rıfat, S.Rıfat, YKY., 1993.

Barthes,Roland. Yazı ve Yorum, Çev. Tahsin Yücel, Metis Yay., 1999.

Baudrillard, J. Kusursuz Cinayet, çev. Necmettin Sevil, Ayrıntı Yay., 1998.

Beckett, Samuel. Godot'yu Beklerken, Çev. Tuncay Birkan, Kabalcı Yay., 1992.

Borchmeyer, Dieter. "Theater (und Literatur)", Moderne Literatur in Grundbegriffen, (hrsg.D. Borchmeyer, V. Zmegac), Frankfurt/M., 1987.

Brasch, Thomas. Kadınlar. Savaş. Komedi, çev.Sibel.A.Yeşilay, Mitos Boyut Yay., 2002.

Brauneck, Manfred. Gerard Schneilin, Theaterlexion, Rowohlts enzyklopadie, 1992.

Brecht,Bertolt. Kafkas Tebeşir Dairesi, Çev.Can Yücel, İzlem Yay., 1980.

Derrida, J.. "Das Theater der Grausamkeit und die Geschlossenheit der Reprasentaion", Schrifft und Differenz, Frankfurt/M., 1976.

Fischer Lichte, Erika-. Semiotik des Theaters Band 2, Gunter Narr Verlag, 1983.

Foucault, M. Bu Bir Pipo Değildir, Çev.Selahattin Hilav, YKY, 1993.

Handke, Peter ."Publikumsbeschimpfung", Die Theaterstïcke, Suhrkamp Verlag, 1992.

Ingarden, Roman. Das literarische Kunstwerk. Mit einem Anhang zu den Funktionen der Sprache im Theaterschauspiel, Tübingen, 1965.

Kaiser, Joachim. "Grenzen des modernen Dramas: Vortrag, gehalten auf dem Germanistentag in Essen", Theater Heute, Heft-12, 1964.

Keim, Katherina. Theatralitat in den spaten Dramen Heiner Müllers, Tübingen, 1988.

Lehmann, H. T. "Theater der Blicke: Zu Heiner Müllers Bildbeschreibung", Dramatik der DDR, (hrsg.U. Profitlich), Frankfurt /M, 1987.

Marquard, Odo. "Kunst als Antifiktion", Funktionen des Fiktiven(Poetik und Hermeneutik)X (hrg.D.Herich,W. Iser). München, 1983.

Patrice, Pavis. Sahneleme, Çev. Sibel Kamber, Dost Yay., 1999.

Pfister, Manfred .Das Drama, Wilhelm Fink Verlag, 1997.

Rifat, Mehmet. (Haz.), Dilbilim ve Göstergebilim Kuramları, Yazko Üretim Kooperatifi, 1983.

Schafer, Rolf. Asthetisches Handeln als Kategorie einer interdisziplinaren Theaterwissenschaft, Aachen,1988.

Schramm, Helmar. "Theatralitat und Öffentlichkeit", Asthetische Grundbegriffe.Studien zu einem historischen Wörterbuch, (hrsg.Wolfgang Thierse), Berlin 1990. 
Schramm,Helmar. "Theatralitat und Öffentlichkeit.", Asthetische Grundbegriffe. Studien zu einem historischen Wörterbuch, (hrsg.K.Barck, M.Fontius, W. Thierse), Berlin, 1990.

Shakespeare, W. Hamlet, çev. Bülent Bozkurt, Hacettepe Üni.Yay., 1982.

Striedter, Jurij. "Einleitung", Dramatische und Theatralische Kommunikation, (hrsg.H.Schimid, J. Striedter), Narr Verlag, 1992.

Watt, Ian - Barthes, Roland. Roman ve Gerçek Etkisi, çev. Mehmet Sert, Corpus Yay., 2002. 